\title{
Effects of Drought
}

Along Pacific Coast

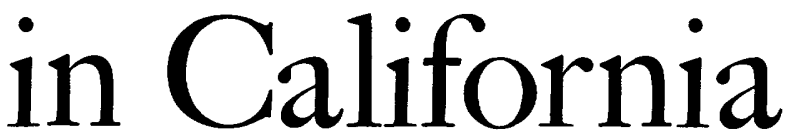

By H. E. THOMAS and others

D R O U G T I N THE S OU T H W E T, 1942-56

GEOLOGICAL SURVEY PROFESIONAL PAPER 372-G

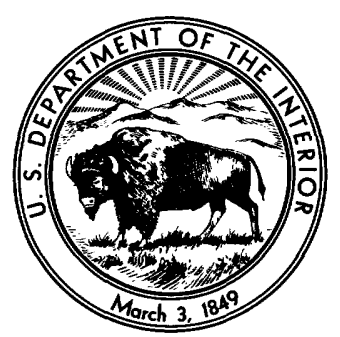

UNITED STATES GOVERNMENT PRINTING OFFICE, WASHINGTON : 1963 


\section{UNITED STATES DEPARTMENT OF THE INTERIOR \\ STEWART L. UDALL, Secretary \\ GEOLOGIGAL SURVEY}

Thomas B. Nolan, Director

For sale by the Superintendent of Documents, U.S. Government Printing Office

Washington, D.C. 20402 


\section{CONTENTS}

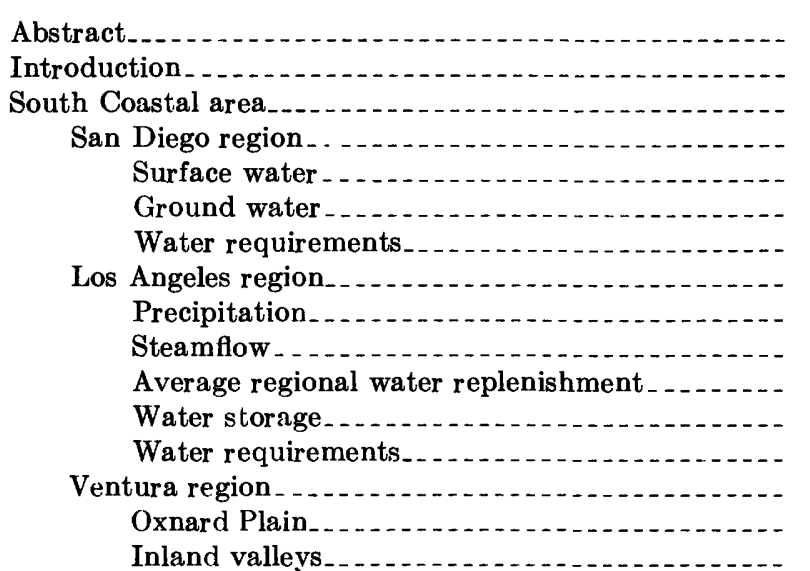

\begin{tabular}{|c|c|c|}
\hline Page & & Page \\
\hline G1 & Central Coastal area & G12 \\
\hline 1 & Santa Barbara region.--- & 12 \\
\hline 1 & Santa Maria River basin & 13 \\
\hline 2 & Santa Maria Valley & 13 \\
\hline 2 & Cuyama Valley & 14 \\
\hline 3 & Santa Ynez River basin $\ldots \ldots \ldots$ & 15 \\
\hline 3 & asins & 16 \\
\hline 4 & ft.--1- & 16 \\
\hline 4 & Upper Salinas River basin, by J. S. Gatewood and & \\
\hline 0 & 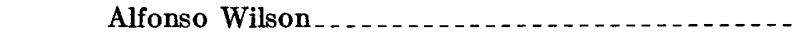 & 19 \\
\hline 6 & Southern San Joaquin Valley, by G. H. Davis & 20 \\
\hline 9 & e area $\ldots \ldots$ & 20 \\
\hline 9 & - & 21 \\
\hline & ------ & 21 \\
\hline 11 & ces cited & 24 \\
\hline
\end{tabular}

\section{L L U S T R A T I O N}

Plate 1. Location map for southern California _. _. - In pocket Figure 1. Runoff of San Luis Rey River and surface storage in San Diego County

2. Runoff of Santa Ysabel Creek and water levels in San Diego region. ...........

3. Water imported into southern California...-

4. Wet and dry periods, Los Angeles region.--

5. Hydrographs for Big Bear Lake and for wells, Los Angeles region.

6. Hydrographs for wells in Ventura region

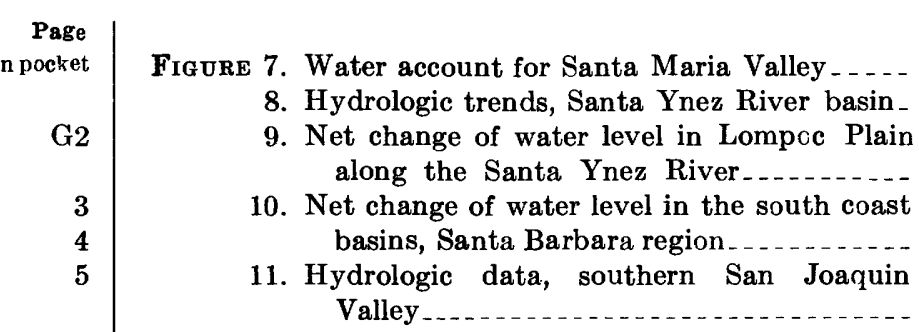

Page

G14

\section{T A B L E}

TABLE 1. Estimated average surface- and ground-water supplies available from local sources, in acre-feet. 



\title{
DROUGHT IN THE SOUTHWEST, 1942-56 EFFEGT OF DROUGHT ALONG PAGIFIC COAST IN CALIFORNIA
}

\author{
By H. E. Thomas and others
}

\begin{abstract}
The drought 1945-56 in California affected principally the southern part of the State, and was one of a series that has been recorded in the past century. Although the precipitation in any individual year is not predictable, the pattern of alternating wetter and drier periods is consistent enough that there is clearly a. need for storing the surpluses of wetter periods to provide adequate water supplies in dry years. This cyclic storage is a basic element in the California water plan. Wherever the storage increments in wet years provide adequate supplies throughout the periods of precipitation deficiency, the effect of drought upon mankind has been overcome, or at least minimized. However, whenever the deficiency is greater than has been experienced in past droughts, some downward revisions may be necessary in previous estimates of the firm supply available for man's use.
\end{abstract}

\section{INTRODUCTION}

To cover the subject of "Drought in the Southwest, 1942-56," Professional Paper 372 includes one chapter on the meteorological phenomenon of drought and another on the general effects of drought throughout the Southwest. Five subsequent chapters describe the effects of drought in the following subdivisions of the Southwest: central and south Texas, the Rio Grande basin, basins of interior drainage, the Colorado River basin, and the Pacific Coast in California. The present chapter is the last of these five.

In southern California, as in other parts of the Southwest where population has been increasing rapidly, it is difficult to identify the effects of natural drought, because of the concomitant effects of increasing development and use of water. However, the problem of finding firm supplies for progressively increasing demands has been with southern California for many years, and its citizens started early to take stock of their water resources. As a result, basic hydrologic records are longer, more detailed, and more complete than for any other area of comparable size in the country. These records have formed the basis for detailed inventories of the water resources in individual drainage basins, which in turn have led to plans (Calif. Div. Water Resources, $1930 ; 1956$ ) for a comprehensive development and use of all the State's water resources.

The effects of drought in the coastal basins of southern California have been described by Troxell in an- other report (1957) as part of a comprehensive analysis of the water resources of the region. He has utilized the abundance of basic data to compute volumetric precipitation upon specific drainage basins in both the wet and dry periods that are characteristic of the region, and has accounted for that water in terms of natural evapotranspiration, water requirements of the population, changes in ground-water storage, streamflow, and waste to the ocean. Troxell's analysis of drought in southern California is considerably more comprehensive than has been possible for other regions of the Southwest. The discussions of the San Diego and Los Angeles regions on pages G2-G9 are based largely upon his report, as shown by numerous references; additions to Troxell's data are based upon data collected since 1951 and upon reports of detailed hydrologic studies in some localities.

In the following discussion of southern California, the South Coastal area and Central Coastal area correspond to areas of the same names as described in California State Water Resources Board Bulletins 1 and $2(1951 ; 1955)$. The southern San Joaquin Valley is the southern part of the Central Valley area as described in those bulletins.

\section{SOUTH COASTAL AREA}

The South Coastal area (pl. 1) had a population estimated to exceed 7 million in 1955 , and thus had more people than in all the rest of the Southwest drought area. The water requirements for many years have exceeded the supply available locally, and by 1956 the Metropolitan Water District was furnishing supplemental imported water to more than 60 cities and water districts serving a total population of $61 / 2$ million.

The effect of the recent drought upon streamflow has been slightly less than that of the 1894-1904 drought (Gatewood and others, 1963). The least runoff in consecutive 2-, 3-, and 5-year periods occurred during the earlier drought. The year and the decade of minimum runoff occurred during the later drought, but the difference between the most infrequent 1-year and 10-year periods in the 1894-1904 and 1944-51 droughts is small. 
Schulman's (1947) studies of tree rings as climatic indicators and conclusions drawn by Troxell (1957) indicate that marked cycles of precipitation and runoff are characteristic of southern California. Periods that are predominantly wet last, on the average, 12.5 years, and those predominantly dry last about 14.5 years. However, much longer periods sometimes occur; the tree-ring record indicates a 43-year dry period from 1490 to 1533 A.D.

\section{SAN DIEGO REGION}

The San Diego region as described by Troxell (1957, p. 57-66) is, in effect, San Diego County, the southernmost county along the Pacific Ocean, and includes the drainage basins of all streams from the Tia Juana River northward to the Santa Margarita River. About 85 percent of the region is mountains and foothills; the rest is composed of narrow alluvial valleys along the main streams, and a narrow belt of terraces along the coast. The volumetric precipitation has not been computed for this region by Troxell; however, he quotes estimates that natural evapotranspiration accounts for 85 to 94 percent of the total precipitation, that the residual would consitute a natural or virgin runoff averaging about 300,000 acre-feet a year, and that average annual wastage to the ocean is about half that amount.

\section{SURFACE WATER}

Like the precipitation, the annual runoff is highly variable from year to year. This variability is shown on figure 1 by the runoff record obtained of the San Luis Rey River at Lake Henshaw near Mesa Grande for the

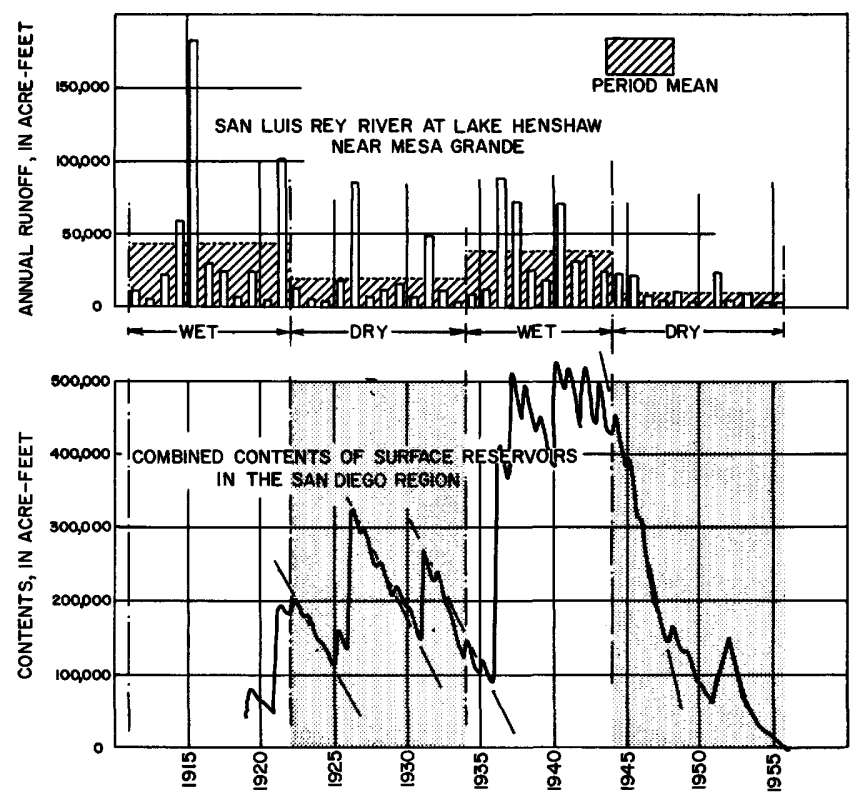

Figure 1.-Annual runoff of San Luis Rey River and combined contents of surface reservoirs in San Diego region. period 1911-56. During the 46-year period the annual runoff exceeded the mean of 26,500 acre-feet in only 11 individual years, but runoff in these 11 years constituted 65 percent of all the runoff in the 46-year period; the last of these "wet" years was 1943 . The time scale on figure 1 has been segregated into wet and dry periods. During the wet period 1912-22 (prior to the creation of Lake Henshaw), the average annual runoff amounted to 43,000 acre-feet, and in the wet period 1935-44 the average annual runoff was 39,000 acre-feet. In the 12-year dry period 1923-34 the average annual runoff was 20,000 acre-feet, and in the drought of $1945-57$ it decreased to 10,000 acre-feet. This distribution is believed to be typical of the runoff throughout the region.

The first reservoirs on streams (Sweetwater and Cuyamaca Reservoirs) were constructed in 1887; by 1950 there had been built more than 30 similar structures, having a combined storage capacity of 730,000 acre-feet, equivalent to $21 / 2$ times the mean annual nat ural runoff, and almost five times the estimated 1950 regional water requirements. The 14 largest reservoirs have a combined capacity of 668,000 acre-feet, or about 92 percent of the total surface-reservoir capacity. As shown in the lower part of figure 1, during the 38-year period $1920-57$ the maximum yearly combined content of these reservoirs ranged from 525,000 acre-feet in May 1941 to 37,000 acre-feet in February 1956, when at least a third was either imported from the Colorado River or pumped from wells.

Except for the imported or pumped water placed in the reservoirs for municipal supply, the contents of the reservoirs represent the cumulative difference between the inflow during the winter rainfall period and the withdrawals necessary to satisfy the water requirements. The inflow during a single wet year can satisfy the water requirements for several years, but it generally takes a series of wet years such as 1937 to 1944 to fill the reservoirs completely. At the beginning of the 1945-57 drought-on April 1, 1945-surface storage amounted to 460,000 acre-feet, but this storage had dwindled to 192,000 acre-feet by December 1947. By December 1951 the reservoirs had a combined content of only about 60,000 acre-feet and many of them were empty. Lake Elsinore in August 1951 was dry for the first time since records began in 1915 (California Water Resources Board, 1953), and, according to newspaper reports, for the first time since 1859. It is obvious that the surface reservoirs of the San Diego region, even though their combined capacity is large in comparison with the water requirements or the average streamflow, are not capable of meeting existing water requirements throughout the recurring protracted dry periods that characterize the climate. 
One may ask whether this surface storage capacity, large though it is, should not be increased further, in view of the wastage of flood water to the ocean, which has been about half of the natural streamflow. Conkling's (1946) studies of reservoirs in the region, however, cast doubt on the feasibility of such a program, for he states that "no matter how large the reservoir capacity, streams of erratic annual and cyclic flow will yield for useful purposes no more than 50 to 60 percent of the average annual discharge because the remainder will be lost, over the years, by evaporation from the excessive water surface of the reservoir necessary to impound the water of the infrequent years of large discharge."

\section{GROUND WATER}

Although there are hundreds of wells in the foothills that yield small ranch and domestic water supplies, the principal ground-water reservoirs in the San Diego region are in the alluvial deposits of such coastal valleys as the Tia Juana, Otay, Sweetwater, San Diego, San Dieguito, San Luis Rey, and Santa Margarita, and such upland valleys as the El Cajon, Santa Maria, Warner, Jamel, and San Pasqual. These alluvial deposits are generally not over 200 feet thick.

According to records from numerous wells in these valleys, the seasonal changes of water level (from winter to summer) have been usually greater than the changes from year to year, and until 1945 were greater

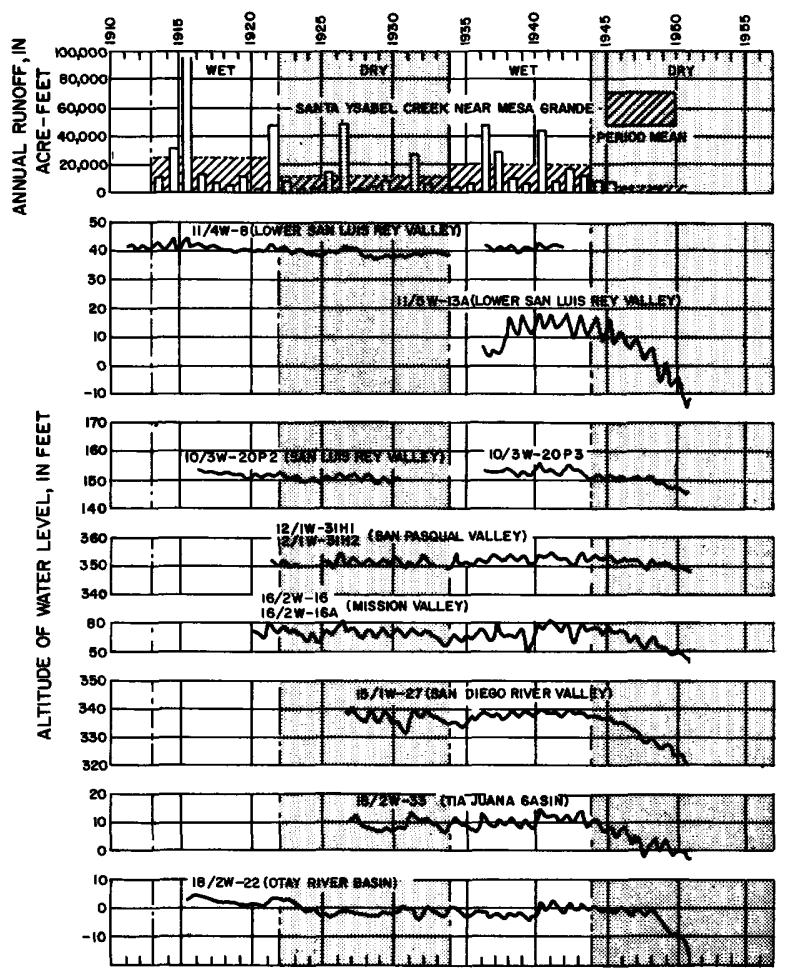

Figure 2.-Annual runoff of Santa Ysabel Creek and water level in selected wells in San Diego region. than the changes from wet periods to dry periods. In the hydrographs of figure 2, the saw-toothed effect of seasonal fluctuations is evident at all wells and quite marked at some. Fluctuations in annual runoff (of which Santa Ysabel Creek is taken as representative) are reflected in fluctuations of water level in several wells, notably in 1922, 1937, and 1941 . In most wells the water levels trended downward slightly in the dry period 1923-34, upward in the wetter period 1935-44, and sharply downward during the drought beginning in 1945. Generally the range of fluctuations in the period of record has been less than 25 feet, which is small in comparison with the maximum 200 -foot thickness of alluvial materials. Before 1945, however, the range of fluctuations was usually less than 10 feet, and the ground-water reservoirs were nearly full at all times.

The depletion of ground-water reserves beginning in 1945 , as shown by declining water levels in wells, has increased the costs of pumping water and has been costly to owners of any shallow wells where the alluvial materials are so thin that their wells have gone dry. But for the region the depletion provides an opportunity and storage space for recharge during wetter periods in the future when runoff will be great enough that some would otherwise be wasted to the ocean. The drawing down of storage in ground-water reservoirs during droughts may permit salvage of water that would otherwise be lost in succeeding wet years.

Water levels in some wells in coastal valleys have been below sea level in recent years, and the landward gradient has induced sea-water encroachment in the lower ends of the San Diego, San Luis Rey and Santa Margarita Valleys; Tia Juana and Otay Valleys are similarly threatened near the ocean. To avert the threat of sea-water encroachment it is necessary to regulate pumping from wells so that the seaward ground-water gradient is not reversed. In the ground-water reservoirs farther inland, depletion of storage during droughts is advantageous unless it is so rapid that the reserves are exhausted before the drought is ended or so great that the reservoir is not filled during the succeeding wet period.

\section{WATER REQUIREMENTS}

Water requirements of San Diego County increased from about 25,000 acre-feet in 1900 to 45,000 in 1920 , and then at an accelerated pace to about 105,000 in 1940 and 150,000 acre-feet in 1950 . This water in 1950 served a population of about 570,000 -mostly in the city of San Diego which used about 55,000 acre-feet of waterplus 90,000 acres under cultivation, of which about 42,000 acres were in fruit and truck-garden crops. 
Since 1950 , the population has continued to increase, and annual water requirements have passed 200,000 acre-feet. For planning purposes, the State Water Resources Board (1955, p. 121-144) has computed the "ultimate" consumptive water requirements of the San Diego region to be about $11 / 2$ million acre-feet, of which 570,000 acre-feet would serve the needs of a population of 2 million and 930,000 acre-feet would be used on 560,000 acres of agricultural lands.

The existing surface reservoir capacity of 730,000 acre-feet was almost five times the annual water requirement as of 1950 , and the maximum recorded storage (525,000 acre-feet in May 1941) would represent about $31 / 2$ years' supply at that rate of demand. As shown in figure 1 the draft upon surface storage was at a rate of about 100,000 acre-feet a year in the first 3 years of the 1945-57 drought; the draft upon ground-water reservoirs was small by comparison, probably less than 20,000 acre-feet a year.

The adequacy of the local water resources to meet the present requirements of the region may be summarized as follows: Alternating wet and dry periods, each about a decade long, are characteristic of the climate; surface reservoirs can be counted on for supply during the first 2 or 3 years of a drought period, provided they are nearly full at the end of the preceding wet period; for the rest of the drought, surface-water supplies are uncertain and probably inadequate. This inadequacy of local supplies in the San Diego region and the need for water importations have long been recognized.

Since November 1947, the local water supplies have been supplemented by importations from the Colorado River. These importations increased from 41,000 acrefeet in 1948 to 74,000 in 1951 and 138,000 acre-feet in 1956 (fig. 3).

\section{LOS ANGELES REGION}

The Los Angeles region comprises the mountainslope, valley, and coastal-plain areas between the $\mathrm{Pa}$ cific Ocean and the crests of the San Gabriel, San Bernardino, and San Jacințo Mountains. It includes the drainage basins of the Los Angeles, San Gabriel, and Santa Ana Rivers and smaller streams entering the ocean along approximately 65 miles of coast. Of the 4,550 square miles within these basins, 2,410 is mountain and foothill, and 2,140 is valley and plain. The latter consist of the coastal plain and four inland valleys-San Fernando, San Gabriel, upper Santa Ana, and San Jacinto Valleys.

The rugged northern and eastern parts of the area attain altitudes exceeding 10,000 feet at San Antonio Peak in the San Gabriel Range, at Mount San Gorgonio

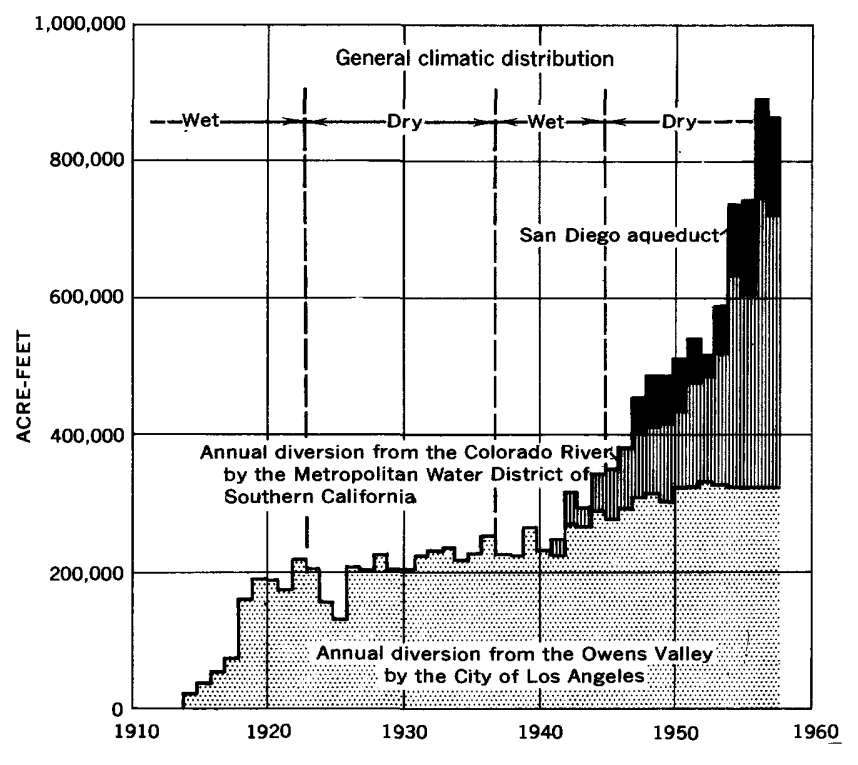

FIGURE 3.-Water imported into southern California.

in the San Bernardino Range, and at San Jacinto Peak in the San Jacinto Mountains. Nearly parallel to these high ranges, the Santa Monica Mountains, Puente Hills, and Santa Ana Mountains form an intermediate range that separates the inland valleys from the coastal plain and roughly bisects the region. The Los Angeles River cuts through the intermediate range at Los Angeles Narrows, the San Gabriel River at Whittier Narrows, and the Santa Ana River at Santa Ana Narrows. The coastal plain lies between the south face of the intermediate range and the ocean. As of 1951, urban and industrial developments occupied about half of San Fernando and San Gabriel Valleys and the coastal plain; most of the remaining lowlands of the area were irrigated agricultural lands. In the upper Santa Ana and San Jacinto Valleys, urban and industrial development accounted for about 8 percent of the total area, and about 35 percent of the valley land was irrigated.

\section{PRECIPITATION}

The volume of precipitation upon mountain-andfoothill areas and upon valley areas has been calculated by Stafford and Troxell (1953, p. 30) for each year since 1920 ; in both areas it is many times greater than the volume of runoff. As shown by figure 4, this period spans two droughts, 1923-34 and 1945-51, and an intervening wet period. Although these long periods are predominantly wet or dry, they are not continuously so. The average annual precipitation in mountainand-foothill areas during the dry period 1923-34 was 2.6 million acre-feet, but the period included 3 relatively wet years in which the annual precipitation exceeded 3.1 million acre-feet. In the wet period 1935-44 the average volume of precipitation in the mountain-and- 

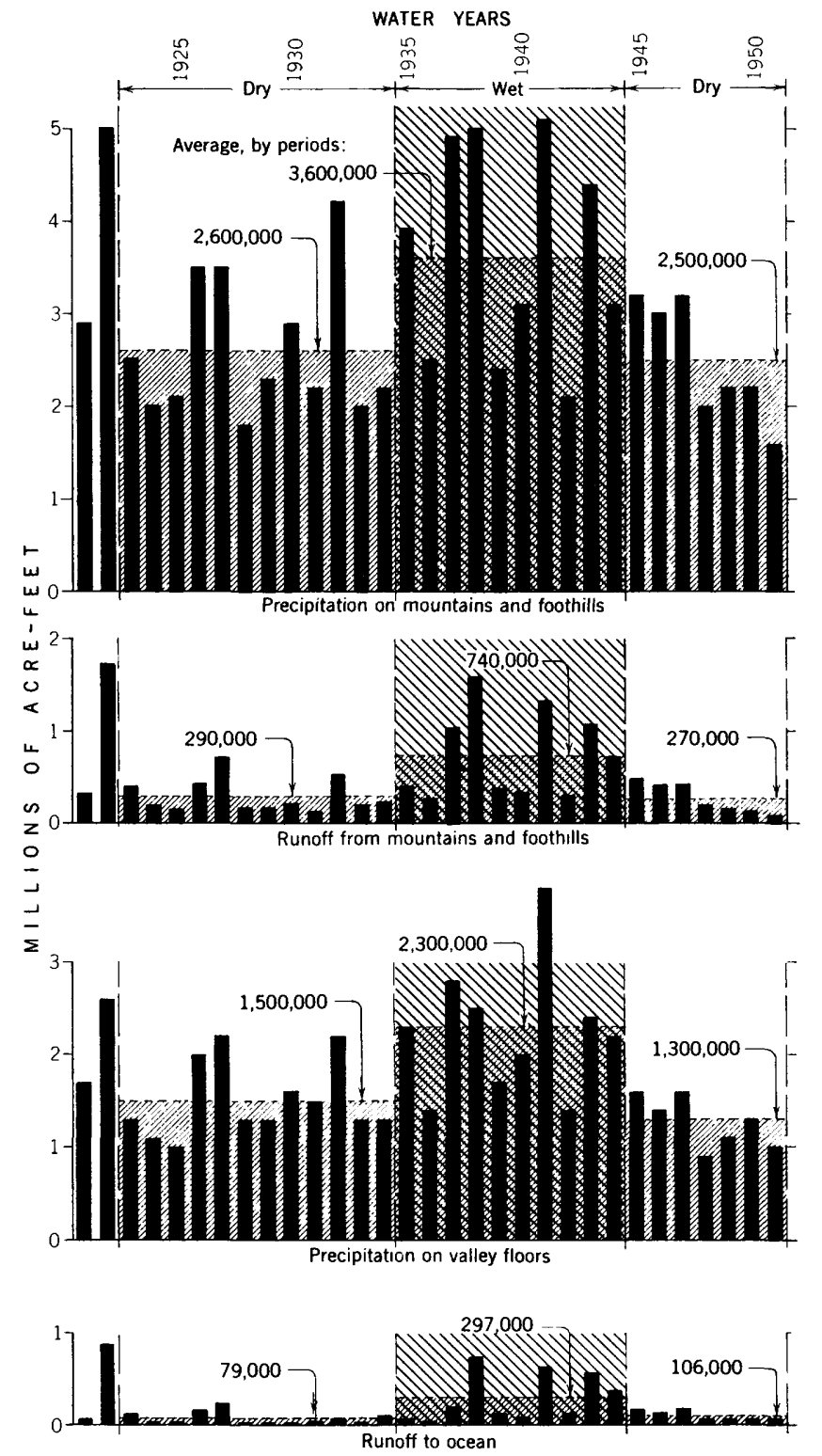

Figdre 4.-Wet and dry periods in Los Angeles region.

foothill areas was 3.6 million acre-feet, but in this 10 year period there were 3 years with less than the mean precipitation. As pointed out by Stafford and Troxell (1953, p. 31):

Volume precipitation in the mountain-and-foothill areas ranged from $1,600,000$ acre-feet in 1951 to $5,100,000$ acre-feet in 1941. The most representative average value is that based on the one wet period plus either one of the two dry periods-that is, on either the 22-year term 1923-44 or the 17-year term 1935-51. From these two, a weighted average yearly value of precipitation volume is $3,100,000$ acre-feet. This is equivalent to a depth of 24 inches over all the area. In the valley areas, the range in precipitation volume was from 900,000 acre-feet in 1948 to $3,800,000$ acre-feet in 1941 . The weighted average is $1,900,000$ acre-feet, equivalent to 17 inches over all the area.
In the entire region (mountain-and-foothill plus valley), the average annual precipitation had a volume of 2.5 million acre-feet during the drought of $1945-51$, which included the driest year in the 31-year period, but also 2 years in which the precipitation slightly exceeded the mean.

\section{STREAMFLOW}

Yearly runoff is more variable than yearly precipitation. In the mountain-and-foothill areas, the volume of precipitation in the wettest year (1941) since 1920 was about $3 \frac{1}{4}$ times the volume in the driest year (1951); but the greatest annual runoff from that area (in 1922) was 19 times as great as the minimum annual runoff (in 1951). In the two drought periods shown on figure 4 the average precipitation on mountain-andfoothill areas was about 70 percent of the average during the intervening wet period, but runoff from the mountain areas during drought was only 33 percent of the average runoff during the wet period.

Of the yearly average $1,500,000$ acre-feet of precipitation on the valley areas plus the 500,000 acre-feet of runoff to the valleys from the mountain-and-foothill areas, about 180,000 acre-feet has run off to the ocean. During the 31-year period 1921-51, half the runoff to the ocean occurred in the 4 years $1922,1938,1941$, and 1943. Stated in another way, the 24 inches of yearly precipitation on the mountain-and-foothill areas and the 17 inches on the valley areas together are equivalent to 21 inches over the entire basin and result in runoff to the ocean equivalent to 0.8 inch. Thus, natural water losses in the mountain-and-foothill areas, together with uses and losses in the valley areas, have resulted in consumption of all but 4 percent of the average yearly precipitation in the 31-year period. The combined flood control and recharge operations of the Los Angeles County Flood Control District and the U.S. Army Corps of Engineers will insure that wastage to the ocean will be even less in the future (Laverty, 1957).

\section{AVERAGE REGIONAL WATER REPLENISHMENT}

The calculated volumes of precipitation on mountain and valley areas, and of runoff from each, have enabled Troxell (1957, p. 75) to estimate the average quantities of ground and surface water available to the region from local sources. Of the precipitation on mountains and foothills, he assumes that the only water available to the valley users is the stream runoff. This is not strictly true because of ground-water movement from mountain to valley, which is an unknown quantity but presumed to be small. Of the precipitation upon valley areas, some is lost by interception and evaporation during and immediately after rainstorms: this is estimated 
to be equivalent to 4 inches of precipitation a year. A larger proportion of the precipitation becomes soil moisture, available for cultivated crops and native plants. On the basis of a regional crop survey, computed consumptive use of individual crops, and measured soil-moisture deficiencies at the end of growing seasons, this quantity has been estimated to range from 6.7 inches per year over the valley areas during drought to 11.1 inches per year during wet years.

The algebraic sums of all the items in table 1 give the regional average annual replenishment to the local water reserves during two dry periods and one wet period. This replenishment amounted to 450,000 acre-feet in the first dry period 1923-34 and to 310,000 acre-feet in the second dry period 1945-51. During the intervening wet period, the average annual recharge increased to $1,170,000$ acre-feet. During one complete wet and dry cycle, embracing the period 1923-44, the annual replenishment was 780,000 acre-feet, and during a second period, that of $1935-51$, annual replenishment was 820,000 acre-feet. On the basis of these two determinations, the regional average annual replenishment is estimated at about 800,000 acre-feet. This represents the estimated "safe yield" of the surface and ground-water reserves of the Los Angeles region under current conditions of climate and development.

TABLE 1.-Estimated average surface- and ground-water supplies available from local sources, in acre-feet

[From Troxell, 1957, p. 70-76]

\begin{tabular}{|c|c|c|c|}
\hline & $\mid \begin{array}{c}1923-34 \\
\text { Dry period }\end{array}$ & $\begin{array}{c}1935-44 \\
\text { Wet period }\end{array}$ & $\begin{array}{c}1945-51 \\
\text { Dry period }\end{array}$ \\
\hline $\begin{array}{l}\text { Mountain-and-foothlll areas: } \\
\text { Precipitation } \\
\text { Evapotranspiration. }\end{array}$ & $\begin{array}{r}2,600,000 \\
-2,300,000\end{array}$ & $\begin{array}{r}3,600,000 \\
-2,900,000\end{array}$ & $\begin{array}{r}2,500,000 \\
-2,200,000\end{array}$ \\
\hline $\begin{array}{l}\text { Net available to valley (surface-water } \\
\text { runoff) }\end{array}$ & 290,000 & 740,000 & 270,000 \\
\hline 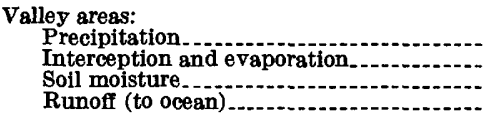 & $\begin{array}{r}1,500,000 \\
-500,000 \\
-760,000 \\
-79,000\end{array}$ & $\begin{array}{r}2,300,000 \\
-500,000 \\
-1,070,000 \\
-300,000\end{array}$ & $\begin{array}{l}1,300,000 \\
-500,000 \\
-650,000 \\
-110,000\end{array}$ \\
\hline $\begin{array}{l}\text { Net available in valley (ground-water } \\
\text { recharge) }\end{array}$ & 160,000 & 430,000 & 40,000 \\
\hline $\begin{array}{l}\text { Total water resources. } \\
\text { Weighted average }\end{array}$ & $\begin{array}{r}450,000 \\
780,0\end{array}$ & $800^{1,170,000}$ & $0,000^{310,000}$ \\
\hline
\end{tabular}

WATPER STORAGE

The method of derivation of the "safe yield" of the local water resources suggests certain prerequisites if those resources are to provide a sustained yield of 800 ,000 acre-feet annually. In the wet period 1935-44 a sustained yield of 800,000 acre-feet a year, or $8,000,000$ acre-feet total, would have been exceeded by $3, \dot{5} 00,000$ acre-feet, but this 3,500,000 acre-feet must be saved up for use at a rate of 500,000 acre-feet a year during the following 7 years of drought, when natural replenish- ment averaged only 300,000 acre-feet annually. Storage is thus essential for utilizing the local resources in quantities approaching the "safe yield."

By far the greatest amount of water storage capacity is in ground-water reservoirs. The maximum thickness of alluvial deposits in the coastal plain, San Gabriel Valley, San Fernando Valley, upper Santa Ana Valley and San Jacinto Valley is known to exceed 1,000 feet, and may reach several thousand feet, most of which is saturated with water. Estimates by Eckis (1934) indicate that the upper 100 feet of these sediments in the five ground-water reservoirs (which were saturated in the 1930's) may contain about 8 million acre-feet of water, or 10 times the estimated "safe yield" of the region.

The total surface storage capacity in the region, including flood-control space, is less than 800,000 acrefeet. Of this capacity only about 300,000 acre-feet may be stored for future diversion and use, in reservoirs constructed primarily for municipal or irrigation supply; the uppermost graph in figure 5 shows the fluctuations of storage in Big Bear Lake, one of these reservoirs in the upper Santa Ana River basin. The rest of the available storage space is in flood-control or multipurpose reservoirs, and is reserved for use in time of flood. By storing water in excess of downstream channel capacities and then releasing it at rates that can be carried by the channels-and perhaps absorbed in recharge basins and spreading areas-these reservoirs serve to minimize flood damage and also to augment recharge to ground-water reservoirs.

The analogy between surface and ground-water reservoirs-as to inflow and outflow, and changes in storage as a measure of the difference between the twohas been mentioned several times in this report. Several distinctions between the two forms of storage have also been pointed out, but nowhere are the distinctions more striking than in the Los Angeles region, chiefly because of the complexity of the ground-water reservoirs. This complexity is a product of the complex geology of southern California and of the intensive ground-water development in many areas, and we are aware of it through studies of the great volume of basic data that have been collected.

The subdivision of the Los Angeles region into five ground-water reservoirs, one in the coastal plain and one in each of the four upland valleys, is only the broadest and most elementary basis of classification. Eckis (1934) divided these five reservoirs into 35 basins, and Gleason (1947) increased the number to more than 50 , separated from each other by faults or other barriers or impediments to ground-water movement. Continued study of the ground-water hydrology in the region has 


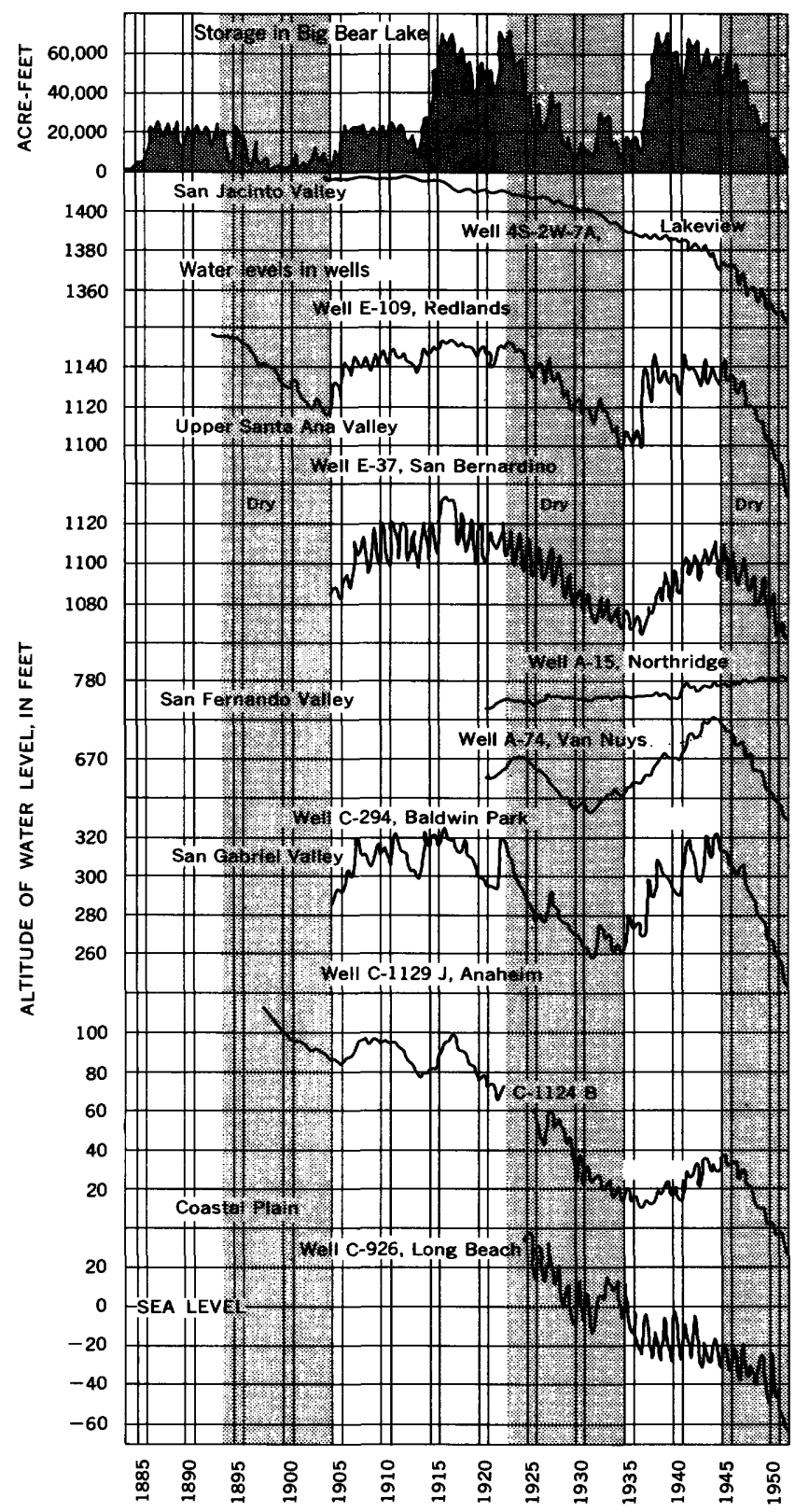

Figure 5.-Hydrographs for Big Bear Lake and for eight wells in Los Angeles region.

shown the existence of many more barriers across which movement of water is impeded, and conduits through which such movement is aided. For example, the upper Santa Ana valley is now known to include many compartments in which water is stored, separated by walls or layers which deter but do not inhibit movement from one compartment to another.

This compartmentation would explain irregularities in the form of the water table, and the locations of springs and "rising water" along stream channels, even under the natural conditions before any well drilling. Under those conditions, fluctuations in the discharge of a single spring, or in the water level in a single well, might give an indication of the changes of storage throughout Santa Ana Valley, but the cumulative effects of pumping, by drawing far more water from some compartments than from others, has drastically changed the natural flow pattern. As a result, simultaneous records in a relatively small area may indicate storage losses in some compartments, gains in others, and practically no change in still others. The great variety of interpretations possible by selective sampling of the abundant basic data is a real bonanza in water disputes, because some evidence may be found in support of almost every conceivable contention.

Any conclusions in the present report as to the effects of drought or development upon the major groundwater reservoirs are necessarily generalizations based on samples selected from the vast amount of available data, and may diverge considerably from conclusions based upon a different selection of data. The following generalizations are based chiefly upon studies by Federal (Troxell, 1957) and State (California Water Resources Board, 1955) agencies, as freely interpreted by the writers of the present report.

All graphs of figure 5 give some indication of the developed storage capacity. Before 1911 the capacity of Big Bear Lake was 25,000 acre-feet, and the reservoir was filled almost every year in wet periods, and even in some years during the 1894-1904 drought; after the capacity was increased to 72,200 acre-feet, it was filled on several occasions during wet periods but not during the droughts of 1923-34 or 1945-51. The other graphs indicate changes in ground-water storage; they show fluctuations of water levels in wells in feet, but these fluctuations are not translatable into volumes of water on the basis of presently available data. The hydrographs ordinarily begin at a high point representing full-reservoir conditions; they trend downward as water is drawn from the reservoir in excess of replenishment, and rise when replenishment exceeds the rate of withdrawal. Thus the storage space developed by pumping is indicated by the deviation of the graph downward from a horizontal line representing full-reservoir conditions. By contrast, the developed storage capacity of the surface reservoir is shown by the maximum deviation of the graph upward from a base line representing zero storage.

The hydrographs for wells are arranged in order of elevation of the water surface above sea level, and therefore include wells in San Jacinto, upper Santa Ana, San Fernando, San Gabriel Valleys, and the Coastal Plain, in that order. The first hydrograph, for a well in the Lakeview-Nuevo sub-basin of San Jacinto Valley, indicates little ground-water development prior to 1915 , 
but a downward trend in the succeeding four decades, at an average rate of about 2 feet a year during the 1923-34 dry period, and then very slowly during the 1935-44 wet period; during the 1945-51 drought the water level declined at a rate of nearly 5 feet a year. The significant features shown by this graph are: (a) The replenishment to the reservoir even in wet years is not enough to balance the rate of withdrawal, and (b) a progressively increasing rate of withdrawal is indicated by the greater rate of decline in water level in recent years.

The wells in upper Santa Ana Valley tap the upper (eastern) part of the ground-water reservoir, near San Bernardino and Redlands. During the 1894-1904 drought the storage in the reservoir was depleted sufficiently to lower the water level 40 feet in well E-109 (adjacent to the channel of the Santa Ana River), but this depletion was erased by replenishment during the next wet period. In the 1923-34 drought the water level in well E-109 declined 50 feet, but replenishment in the succeeding wet period again resulted in a rise to a maximum within a few feet of the original water level. In the 1945-51 drought the water level dropped about 70 feet, and the rate of decline was more than twice as great as in the earlier droughts. The increased rate of decline reflects increasing withdrawals in recent years, and raises the question whether the replenishment in the next wet period will be great enough to offset the depletion in storage during the drought that began in 1945. The hydrograph for well E-37 shows that in the part of the reservoir near San Bernardino the replenishment during the 1935-44 wet period' was not enough to make up for the withdrawals during the 1923-34 drought. In the western part of the valley, near Chino, water levels in representative wells have declined throughout each dry period, and have barely held their own in the intervening wet periods. In other words, in some parts of the upper Santa Ana Valley the current rate of pumping clearly exceeds the long-term average replenishment, and water is being mined.

Some of the wells in San Fernando Valley show a trend in ground-water storage unlike that in most other parts of the Los Angeles region. At well A-15 in the upper (western) part of the valley, the water level has risen progressively since the record began in 1921 . The water level in well A-74 near Van Nuys declined during the dry periods $1923-34$ and 1945-51 and rose during the preceding and intervening wet periods; it thus conformed to the alternations shown at other wells in the region, but the maximum water level reached during the 1923-34 wet period was 20 feet higher than that reached in the preceding wet period. The explanation for this increasing storage in the San Fernando groundwater reservoir lies in the availability of imported water from Owens Valley beginning in 1913. Because of this availability, there has been less effort to achieve full utilization of the local resources, the storage in the ground-water reservoir has been augmented by the return flow of irrigation water and recharge from precipitation, and some parts of the valley in the 1935-44 wet period were troubled with high water table and waterlogged land-a rare affliction in the Los Angeles region. During the period of drought beginning in 1945, water levels declined slightly in the western half of San Fernando Valley, and more sharply in the eastern part which is subjected to heavier pumping from wells.

In the San Gabriel Valley, as shown by the record from the Baldwin Park well C-294, the replenishment in the 1935-44 wet period was evidently sufficient to make up for the draft on storage in the preceding dry period; other wells in the valley similarly suggest that the "safe yield" of the reservoir had not been exceeded by 1945 . However, a more rapid rate of decline of water levels during the 1945-51 drought reflected increased pumping from the reservoir.

In the coastal plain, the trends in water levels in representative wells are similar to those in San Jacinto Valley and upper Santa Ana Valley: downward during droughts and horizontal or slightly upward during wet periods, but with insufficient replenishment to balance the withdrawals during drought. One additional feature is shown by the hydrograph for well C-926 near Long Beach: Depletion of the ground-water reservoir has progressed to the point where the water levels are now lower than sea level, and the gradients are such that sea-water encroachment into the reservoir is inevitable unless there is some barrier to prevent it. For the coastal plain as a whole, the steadily increasing rates of decline in water levels in wells during dry periods, and the lack of recovery during substantial wet periods, indicate that the ground-water reservoir has been overdeveloped, and that an "overdraft" now exists (see p. G16). The overdraft upon ground-water reservoirs in the Los Angeles region - that is, the extent to which the storage is being depleted in excess of the long-term average replenishment-has been estimated as follows: 
Estimated overdraft on ground-water basins in the Los Angeles region

[From Richter (1956)]

\begin{tabular}{|c|c|c|}
\hline \multirow{2}{*}{ Area } & \multicolumn{2}{|c|}{ Estimate } \\
\hline & Year & $\begin{array}{l}\text { Overdraft } \\
\text { (acre-feet } \\
\text { per year) }\end{array}$ \\
\hline \multicolumn{3}{|l|}{ Upper Santa Ana Valley: } \\
\hline Elsinore basin......... & 1948 & 6,000 \\
\hline Bunker Hill basin.-- & 1953 & 6,000 \\
\hline Chino basin & 1948 & 17,000 \\
\hline \multicolumn{3}{|l|}{$\begin{array}{l}\text { Pomona basin } \\
\text { San Gabriel Valley: }\end{array}$} \\
\hline \multicolumn{3}{|l|}{$\begin{array}{l}\text { San Gabriel Valley: } \\
\text { Spadra unit }\end{array}$} \\
\hline \multicolumn{3}{|l|}{$\begin{array}{l}\text { Spadra unit } \\
\text { Coastal plain: }\end{array}$} \\
\hline $\begin{array}{l}\text { La Habra } \\
\text { Irvine basin }\end{array}$ & 1945 & 500 \\
\hline $\begin{array}{l}\text { Irvine basin } \\
\text { Santa Ana forebay }\end{array}$ & $\begin{array}{l}1945 \\
1953\end{array}$ & $\begin{aligned} 2,700 \\
71,000\end{aligned}$ \\
\hline $\begin{array}{l}\text { Santa Ana forebay } \\
\text { Orange County }\end{array}$ & $\begin{array}{l}1945 \\
1950\end{array}$ & $\begin{array}{l}10,200 \\
77,000\end{array}$ \\
\hline \multirow{2}{*}{$\begin{array}{l}\text { Los Angeles forebay } \\
\text { Remainder of coastal plain. }\end{array}$} & $\begin{array}{l}1953 \\
1945\end{array}$ & $\begin{array}{r}100,000 \\
22,000\end{array}$ \\
\hline & \multicolumn{2}{|c|}{ No estimate 22,000} \\
\hline
\end{tabular}

WATER REQUIREMENTS

The water requirements of the Los Angeles region are estimated by Troxell $(1957$, p. 69) to have increased with the burgeoning population from about 200,000 acre-feet in 1900 to 400,000 in 1910 and 800,000 acrefeet in 1922. Since that year the water requirements have doubled again, having passed 1 million acre-feet by about $1942,1.4$ million by 1950 , and 1.6 million acrefeet by 1956. These estimated requirements include water for both consumptive and nonconsumptive uses, but most of the nonconsumptively used water has been sewered to the ocean and not reused.

Even before 1922, when the water requirements reached the estimated potential sustained yield of the local resources, storage in some ground-water reservoirs was depleted locally during dry periods and not fully replenished in succeeding wet periods. Since 1923, however, the requirements have exceeded the estimated average sustained yield of the region. The growing disparity between requirements and net local water supply has been overcome by overdraft upon groundwater storage and by importations from outside sources.

Importations began in 1913 from Owens Valley, through an aqueduct that since 1941 has been carrying water from the Mono Basin also (Thomas and others, 1963). Since 1947 the rate of importation has been about 320,000 acre-feet a year, which is about the capacity of the Owens Valley aqueduct. The Colorado River aqueduct was completed in 1942 to carry 1,605 cfs (cubic feet per second) or 1,150,000 acre-feet a year, except for the pumps and siphons that have a present capacity of $600 \mathrm{cfs}$, or 430,000 acre-feet a year. As of 1950, the combined importations into the Los Angeles region through both aqueducts totaled 417,000 acrefeet; by 1956 the importations had increased to 776,000 acre-feet (fig. 3 ).
Almost all the increase in importation of Colorado River water between 1954 and 1955 (about 130,000 acrefeet) was used to recharge ground-water basins, particularly those in the Orange County Municipal Water District and the Los Angeles County Flood Control District. In the vicinity of Manhattan Beach, 2,760 acre-feet of Colorado River water was injected into wells to build a fresh-water barrier against sea water that is beginning to encroach on the ground-water aquifer (Laverty, 1957). For many years the Los Angeles County Flood Control District has increased the recharge of flood water to the ground-water reservoirs by artificial means: The acreage of spreading grounds increased from 2,440 acres in 1946 to 3,000 acres in 1956 ; ground-water recharge basins completed by 1956 have a capacity of 3,500 acre-feet.

The nonconsumptively used water discharged to the ocean by outfall sewers in the Los Angeles region has increased from about 120,000 acre-feet in 1928 to 200,000 in 1940 and 360,000 acre-feet in 1950. Methods of reclaiming some part of this wastage to the ocean, for possible use in industry or agriculture, have been studied intensively by various agencies, including the City of Los Angeles, the Los Angeles County Sanitation District, and the State of California. To meet the increasing requirements of the future, the reclamation and pumping of sewage effluent to points of demand would undoubtedly be less expensive than importations from remote sources still untapped.

\section{VENTURA REGION}

The Ventura region is a mountainous area of about 2,200 square miles, which includes most of Ventura County and part of Los Angeles County. The topography is characterized by eastward trending mountains and valleys with a maximum relief of nearly 6,000 feet, bounded on the northeast by the San Gabriel Mountains and on the southwest by the Pacific Ocean. Mean annual precipitation ranges from 12 inches along the coast near Point Mugu to 30 inches in the headwaters of Sespe Creek and back to 9 inches in the desert "headwaters" of Santa Clara River. It has been estimated (California Water Resources Board, 1953, rev. 1956) that the average runoff from mountains and foothills is about 350,000 acre-feet, of which about two-thirds is wasted to the ocean under the present pattern of land use and water-supply development. Precipitation from year to year varies considerably, and runoff even more so; alternating wet and dry periods of several years' duration are also delineated by long-term records. Drainage is principally by Ventura River, Santa Clara River, and Calleguas Creek. 
Urban and agricultural development is limited to the valley lands, which constitute about 15 percent of the total land area. The cities of Oxnard and Ventura on the coastal plain, and Santa Paula some distance inland on the Santa Clara River, are the principal population centers. Development of water resources has been hastened by the growing importance of agricultural crops (valued at $\$ 66$ million in 1951) and by the increasing population which has octupled in 50 years. Troxell (1957, p. 93) has estimated the annual pumpage from wells by the city of Oxnard, and uses this trend as an example of the development of water for urban areas in the Ventura region since the Second World War: The annual water deliveries in Oxnard of 1,350 acre-feet in 1941 increased 217 percent to 4,280 acre-feet in 1951.

The agricultural economy of the region was originally one of stock raising, but as early as 1880 it was changing to intensive, irrigated cultivation, especially of citrus and beans. The irrigated area in the region increased from about 12,000 acres in 1900 to 89,000 in 1930 and to 110,000 in 1950 , and the water required for irrigation increased from about 15,000 acre-feet in 1900 to 140,000 in 1950 .

The geology and hydrology of the Ventura region are complex, as shown in a report of a detailed investigation recently completed of Ventura County (California Water Resources Board, 1953, rev. 1956).

Extensive utilization of ground water is responsible for the region's present stage of development. Before 1955, the 7,000-acre-feet capacity Matilija Reservoir (constructed in 1948 on a tributary of Ventura River) was the only significant surface storage facility, and direct use of surface water is limited to a relatively fow inhabitants along the Ventura and Santa Clara Rivers. The 17 ground-water basins that have been delineated each have their distinctive geology, water supply, patterns of development, and water problems. In the following discussion these basins are grouped into those that underlie the Oxnard Plain, extending along the coast from Ventura to Point Mugu and inland as much as 10 miles, and those that are in valley areas farther inland and farther above sea level. A major hydrologic distinction between these two groups is that the Oxnard Plain is adjacent to the Pacific Ocean and the inland areas are not.

\section{oxnARD PLAIN}

The Oxnard Plain has been formed chiefly by deposition of sediments from Santa Clara River and Calleguas Creek, and it has the form of a compound alluvial fan with apices near Saticoy and near Somis; its aggregate area is about 100 square miles, and it is mostly less than
100 feet above sea level. The principal aquifer of the Oxnard Plain (the Oxnard aquifer) is gravel and sand having a base about 200 feet below sea level and found only to the south of the Santa Clara River, but extending at least to the coast and possibly cropping out in submarine canyons within a mile of the shore. The sand and gravel are at the surface in a "forebay" area of about 10 square miles southwest of Saticoy; in this area the water in the aquifer is unconfined, and is recharged naturally from stream channels and irrigated areas, and artificially from spreading grounds near Saticoy. Elsewhere the Oxnard aquifer is buried beneath a clay bed 50 to 150 feet thick, and the water confined in that part of the aquifer originally flowed under artesian pressure. Gravel and sand beds occur above this clay bed in many places, and they carry unconfined water, but the water is of poor quality and is not used.

About one-fourth of all the irrigated area in the Ventura region is served by wells pumping from the Oxnard aquifer; the pumpage is estimated to have been 65,000 to 70,000 acre-feet a year during the wet period 1936-44, and to have increased to an annual average of 97,000 acre-feet in the dry period 1945-51. The hydrographs for wells $2 \mathrm{~N} / 22 \mathrm{~N} 23 \mathrm{H}$ and $1 \mathrm{~N} / 22 \mathrm{~W} 3 \mathrm{~F} 4$ (fig. 6) are representative of the changes in water level observed in wells on the Oxnard Plain: a downward trend in the dry period 1917-32, a more marked trend in 1945-51, and upward trends in other and wetter years. These cyclic fluctuations are doubtless attributable in part to fluctuations in recharge, and in part to increased rates of pumping in dry years. The downward trends result directly or indirectly from drought.

In 1951 the water levels in wells in the eastern part of the Oxnard Plain were as much as 50 feet lower than they had been in 1935, at the end of a preceding dry period, and they were as much as 90 feet lower than in 1944 , at the end of the intervening wet period. Whether the storage depletion during 1945-51 will be replaced by recharge during the next wet period can be answered only in the future; at present we do not know that the aquifer storage has been depleted beyond the local capabilities for replenishment.

The proximity of the Pacific Ocean is a factor of the problem here because the water levels in wells at the end of 1951 were below sea level throughout most of the Oxnard Plain-specifically in a belt extending inland about 7 miles from the coast. The piezometric surface for the confined part of the Oxnard aquifer had formed a trough more than 10 feet below sea level and extending parallel to the coast through the pumping district south of the town of Oxnard. In the 3-mile-wide strip west of this trough, the natural seaward gradient was reversed, and conditions were rife for sea-water intrusion 

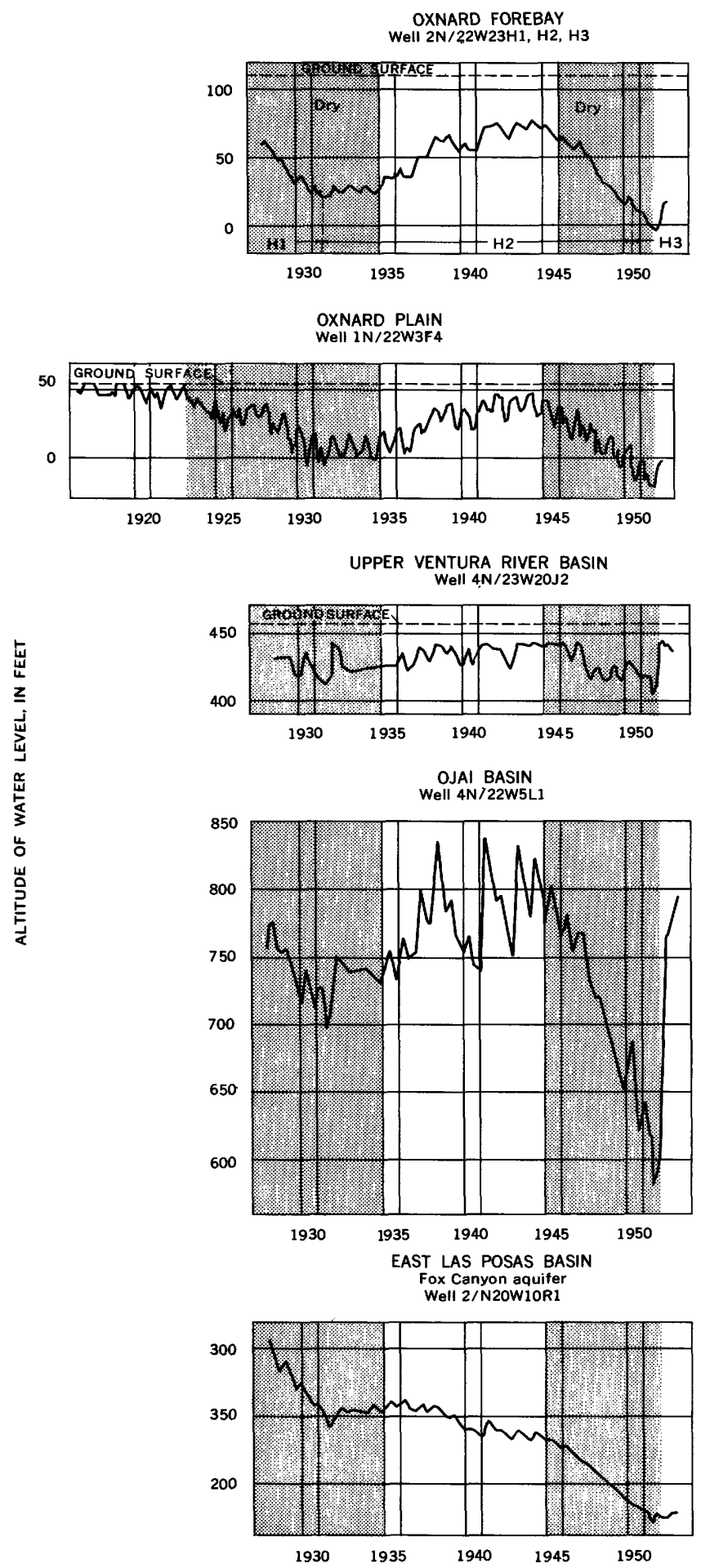

Figuan 6.-Hydrographs for wells in Oxnard Plain and other areas in Ventura region.

into the aquifer, provided the aquifer is open to the ocean. Four wells in the immediate vicinity of Port Hueneme provide evidence that there had indeed been encroachment of sea water into the Oxnard aquifer near the coast by the end of 1951 .
The trough in the piezometric surface of the Oxnard aquifer first appeared in 1946, at a location about 3 miles inland from the coastline and southeast of Oxnard. It subsequently disappeared, but reappeared during months of greatest pumping draft in 1947 and 1948. From early in 1949 the trough, with its center substantially below sea level, persisted until the wet year 1952 . The existence of conditions favorable for sea-water intrusion represents an adversity that constitutes "overdraft" (p. G16) even though the ground-water storage in the aquifer may not have been depleted during drought to an extent beyond the capabilities of replenishment in subsequent wetter years.

Beneath the Oxnard aquifer there are other waterbearing formations, but these have generally been folded and faulted. In some places they are more than 1,000 feet below sea level, but in the part of the Oxnard Plain north of Santa Clara River, some are at shallow depth and constitute the principal aquifers; this is also true in Pleasant Valley east of the plain. In parts of these aquifers, as in the Oxnard aquifer, water levels have been depressed below sea level by pumping, and conditions are favorable for salt-water intrusion through any permeable zones that extend to the ocean.

\section{INLAND VAITEYS}

The ground-water basins inland from the Oxnard Plain include the upper and lower basins along the Ventura River, and Ojai and Upper Ojai Basins which are also within the Ventura River drainage basin. In all these basins the water-bearing materials are sand and gravel, and their storage capacity is small in comparison to their capabilities for ground-water replenishment and disposal. As indicated by the hydrograph of well $4 \mathrm{~N} / 23 \mathrm{~W}-20 \mathrm{~J} 2$ (fig. 6), the recharge in upper Ventura Valley in most winters is sufficiently large to restore all the depletions made during the preceding dry months. By contrast, the Ojai Basin is rapidly depleted during extended dry periods, but is quickly recharged during wet periods, as shown by the hydrograph for well $4 \mathrm{~N} / 22 \mathrm{~W}-5 \mathrm{~L} 1$ on figure 6 .

In the Santa Clara River drainage basin, the Piru, Fillmore, and Santa Paula basins all overlie the Santa Clara River syncline, and the Recent alluvium is underlain by permeable materials that may be as much as 4,000 feet deep, of which only the upper 1,000 feet are presently tapped by wells. The Piru Basin is the easternmost and highest of the basins. The Fillmore Basin is a narrow valley along the Santa Clara River between the towns of Fillmore and Santa Paula, and the Santa Paula basin is another valley just downstream from the Fillmore basin. In all the basins the ground water is generally unconfined. As in the Ventura River areas, 
quick response to recharge and discharge is characteristic of these valleys, and deep wells may be required for firm supply because of the widely fluctuating water levels. In the Piru Basin, water levels in 1951 were as much as 50 feet below the levels of 1936, and 150 feet lower than in 1944 at the end of a wet period. The Santa Felicia Dam near Piru was completed in 1955 to provide storage chiefly for controlled release of water to spreading grounds for recharge of ground water.

The situation is somewhat different in most of the drainage basin of Calleguas Creek, which includes several areas (Simi Valley, Las Posas Valley, Santa Rosa Valley) where water has been pumped for several decades, pumped from water-bearing formations which have been intensely folded and faulted. The hydrograph for well $2 \mathrm{~N} / 20 \mathrm{~W}-10 \mathrm{R} 1$ (fig. 6) believed to be representative of these areas, shows a general decline of water level since 1927 and little or no recharge during wet periods, that is, it indicates mining of the groundwater resources.

\section{CENTRAL COASTAL AREA}

The Central Coastal area, which includes the coastal drainage basins from Santa Barbara northward to Santa Cruz, is only partly within the area of longcontinued drought as delineated by Thomas (1962). Precipitation has been significantly less than the longterm mean in 11 of the 16 years $1942-57$ at San Luis Obispo, and this station is primarily responsible for the position of the line defining the northern limit of drought along the Pacific Coast. However, at other stations farther south, including those at Santa Maria and Santa Barbara, the precipitation deficiency has been less marked, and the entire Central Coastal area may thus be considered marginal with respect to the Southwest drought.

The effects of the drought of 1945-57 in the Central Coastal area were less marked than in the South Coastal area. According to Gatewood and others (1963), the runoff with the lowest time frequency since 1896 occurred during the 1923-34 drought on the basis of $1,2,3,5$, and 10 consecutive-year periods. The same is true on the basis of percent of normal flow except that in the 5 consecutive years $1946-50$ the average flow was slightly less than in 1930-34. Ground-water reservoirs are accessible to almost all the economically important localities. Additional ground-water supplies developed in the region during the period $1945-57$ were necessary, not because of the drought, but because of growth of population and industry. The principal effect of the drought was to lower ground-water levels more than they would have been had runoff been average.

\section{SANTA BARBARA REGION}

The Santa Barbara region, the northernmost of those treated by Troxell (1957) in his drought report, forms the most pronounced corner along the California coast. It has a rectangular area of about 3,400 square miles, and its west and south borders are formed by the Pacific Ocean. Its topography is dominated by four westwardtrending mountain ranges (Santa Ynez, San Rafael, Sierra Madre, and Caliente) which form the divides separating the Santa Ynez River, the Santa Maria River and its extension the Sisquoc, and the parallel tributary Cuyama River. Mountains and foothills comprise nearly 90 percent of the total area of the region. The potential agricultural lands have been estimated to be slightly less than 300,000 acres, of which more than 60,000 were being irrigated in 1950. Agricultural products in 1955 (mainly cattle, lemons, lettuce, dairy products, and dry beans) had a value of about $\$ 56$ million.

The population is concentrated in the parts of the region where the natural water resources are least. In 1955 about half the total population of 110,000 was in the south coast communities of Santa Barbara, Montecito, Carpinteria and Goleta, which occupy alluvial plains generally less than 3 miles wide. The streams debouching onto these plains are short, steep, and dry most of the year, and the local water supplies have been augmented for several decades by transmountain diversions from the Santa Ynez River.

The city water departments of Santa Barbara and Santa Maria are the largest water service units of the region. The annual deliveries to Santa Barbara increased from 3,400 acre-feet in 1921 to 7,700 acre-feet in 1955, and deliveries to the city of Santa Maria increased from 500 acre-feet in 1921 to 2,700 acre-feet in 1955. Troxell $(1957$, p. 104) considers this growth trend typical of the increase in water requirements of the urban areas of the region. The agricultural water requirements have grown even more markedly, for irrigated acreage of 3,200 acres in 1900 had increased to 60,400 acres by 1950 . On the basis of per-capita urban water consumption, supplemental irrigation requirements and census data, Troxell estimates that the regional water requirements increased from 6,200 acrefeet in 1900 to 78,000 acre-feet in 1950 .

It has been estimated (California Water Resources Board, 1951) that prior to 1950 the average annual runoff from the mountain and foothill areas was about 330,000 acre-feet, of which perhaps 180,000 acre-feet was wasted to the ocean. This runoff is very uneven and erratic. For example, 50 percent of the runoff of the Santa Ynez River near Santa Ynez occurs in 1 percent 
of the time or 3.6 days per year, and 90 percent of the runoff occurs in 10 percent of the time, or 36 days per year. Large surface-storage facilities for this runoff were not available until completion in 1955 of the Cachuma Dam created a reservoir on the Santa Ynez River with capacity of 210,000 acre-feet. Before 1956, therefore, most of the water used within the region was derived from ground-water reservoirs. These sand and gravel aquifers are replenished during times of abundant precipitation and flood runoff.

\section{SANTA MARIA RIVER BASIN}

The Santa Maria River basin encompasses an area of about 1,800 square miles, of which 1,600 are in the basins of the Cuyama and Sisquoc Rivers; these two rivers join to form the Santa Maria. Santa Maria Valley is an alluvial plain bordering the Santa Maria River, and it joins a similar but narrower plain along the lower 8 miles of the Sisquoc River. Upstream from these alluvial plains, the Sisquoc and Cuyama Rivers and their tributaries flow in narrow valleys in mountainous terrain, except for Cuyama Valley in the northeast part of Santa Barbara County.

The runoff from these mountainous headwaters fluctuates greatly. Since 1930 the greatest yearly runoff (in 1941) of the Cuyama River was 21 times the least (in 1934), and in the tributary Huasna River the maximum (also in 1941) was 259 times the minimum (in 1931) ; both streams have discharged more than 24,000 acre-feet in some months, and both have been dry for periods of several months. Throughout the drainage basin there were no surface reservoirs as of 1957 to store the flood runoff for later use, and during periods of maximum flow considerable water was discharged to the ocean. However, there are large ground-water reservoirs in both Santa Maria Valley and Cuyama Valley, and these are the principal storage facilities in the Santa Maria drainage basin.

\section{SANTA MARIA VALIEY}

The following summary of the hydrology of Santa Maria Valley is based chiefly upon a detailed report by Worts (1951) and supplementary data by Wilson (1957). The alluvial plain of the Santa Maria Valley extends from the Pacific Ocean inland along the lower Sisquoc River about 28 miles; its maximum width is about 5 miles, near Guadalupe. A single ground-water reservoir underlies this plain and adjacent terraces throughout an area of 110,000 acres; its thickness averages 1,000 feet and it has an estimated volume of 100 million acre-feet of saturated sediment. In the westernmost 8 miles of the valley, the water is confined beneath alluvial clay and silt; wells as much as 5 miles from the ocean were yielding water by artesian flow in 1918 (even the wells nearest to the ocean have ceased to flow in recent years). Under the eastern 80,000 acres of the plain the water is unconfined; this is the area where recharge occurs chiefly by seepage of surface water but also by direct infiltration of precipitation.

As shown by Thomasson (Worts, 1951, p. 48-72) there is always some seepage from the Santa Maria River as it traverses Santa Maria Valley. In years of minimum inflow to the valley there is no surface outflow to the ocean, and in 5 years of highest runoff the outflow to the ocean was just half of the inflow to the valley. In the uppermost chart of figure 7, the total water available annually for recharge of the Santa Maria Valley ground-water reservoir is indicated by the length of bars above the 0 -line; the solid black part indicates escape by surface outflow to the ocean, and the remainder indicates the actual ground-water recharge, both from streams and from precipitation upon the valley. From this annual recharge is subtracted the estimated amount of subsurface outflow to the ocean (shown by vertical ruling) and the net quantity of water withdrawn from wells, computed as 80 percent of the total irrigation pumpage plus all pumpage for other uses (shown by diagonal shading). In years when the discharge from the reservoir exceeds the recharge to it, these shaded bands project below the 0-line.

The lower part of figure 7 shows the cumulative difference between total inflow (surface water plus percolation from rainfall) and total outflow (surface and subsurface flow to the ocean plus net withdrawal from wells), which thus represents cumulative changes in storage since 1930. A nearly parallel graph shows the fluctuations of water level in a well in the town of Santa Maria since 1917. For the period since 1930, the estimated changes in storage can be correlated with climatic fluctuations. During the dry period 1930-36, the recharge averaged only 34,000 acre-feet a year, and the net storage decreased 160,000 acre-feet or more. In the wet period $1937-44$, the recharge averaged nearly 100,000 acre-feet a year, and the net increase in storage was about 260,000 acre-feet. In the dry period $1945-$ 55 , the recharge was only 23,000 acre-feet a year, and the decrease in storage amounted to 650,000 acre-feet.

Throughout the period covered by figure 7 the natural balance has been modified by pumping. By 1930 about 75 percent of the 35,000 acres of the Santa Maria Valley and Sisquoc River plains was being irrigated, and since 1944 the plains have been almost 100 percent irrigated. Since 1930, therefore, the ground-water reservoir has been coming closer and closer to a new equilibrium in which the principal discharge has been through pumped 


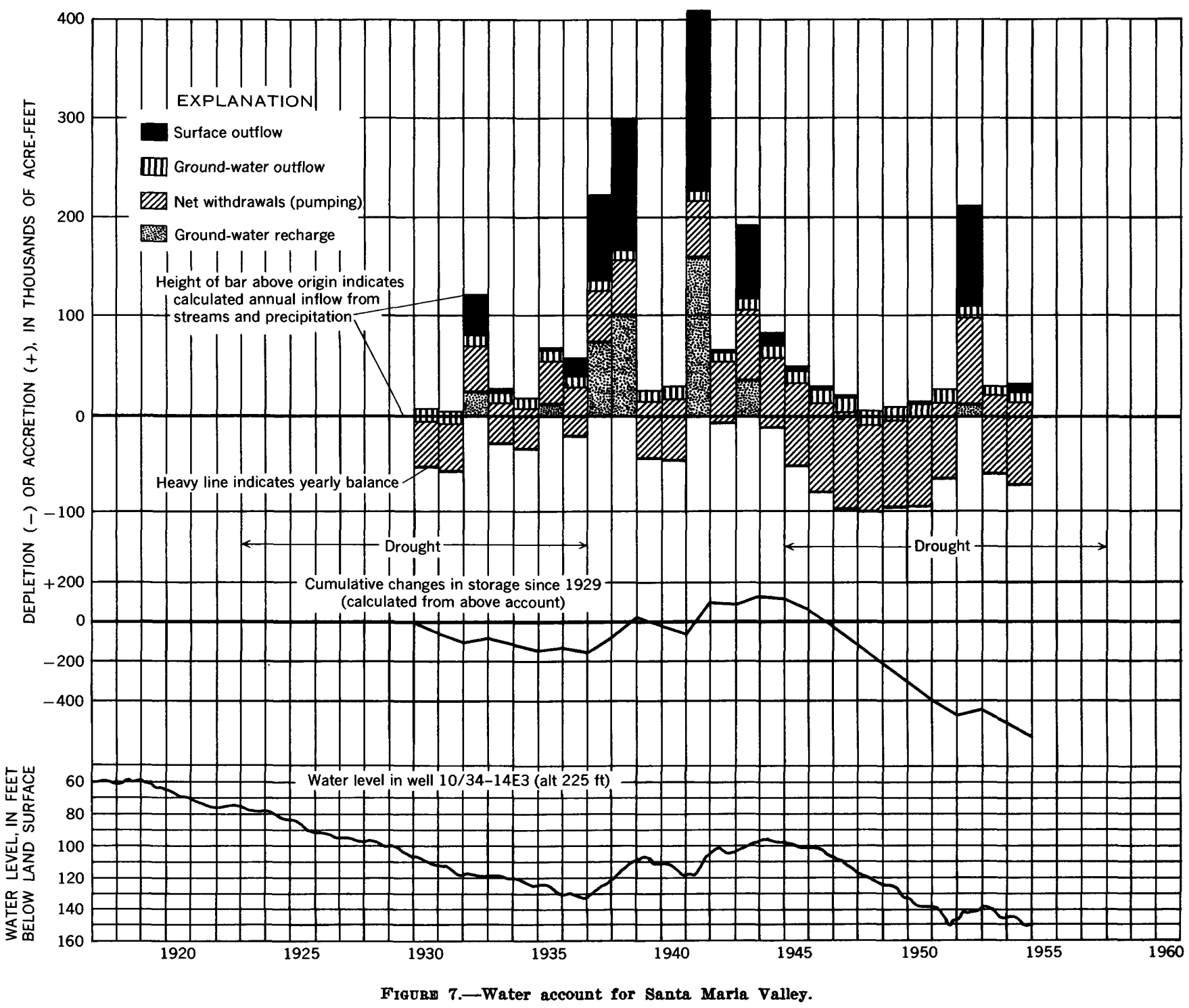

wells; these wells have thus replaced ground-water overflow at the upper edge of confining alluvial clay, upward seepage through that clay, and surface outflow as the principal means of discharge from the valley. The change from the natural equilibrium to the pumping equilibrium appears to have been accompanied by a permanent loss of storage, at least in some parts of the valley, as indicated by the fluctuations of water level in well 10/34-14E3 in Santa Maria. The record from this well begins in 1917 and thus covers the entire period of rapidly increasing ground-water development in the 1920's. The water level in the well declined each year from 1919 to 1931, with the single exception of 1922 when rainfall and runoff in the region were generally above the long-term average.

\section{CUYAMa VALLEY}

As described by Upson and Worts (1951), Cuyama Valley is an intermontane basin, largely structural in origin, situated about midway along the course of the Cuyama River. The valley floor is more than 2,000 feet above sea level, and has a length of 12 miles and a maximum width of 5 miles. The valley is on the landward side of the Coast Ranges and receives less than 10 inches of rain in an average year.

The Cuyama Valley floor is underlain by alluvium generally 150 to 250 feet thick, and by older continental deposits to a total depth of 3,000 to 4,000 feet. These unconsolidated deposits composed of gravel, sand, silt, and clay, are generally coarser in the eastern part of the valley, and form a ground-water reservoir that is recharged chiefly by the Cuyama River, which rises in mountainous terrain at altitudes ranging from 6,000 to 8,800 feet above sea level. The Sierra Madre south of Cuyama Valley also contributes to recharge of the valley ground water, both through tributary creeks and subsurface flow in unconsolidated deposits. Recharge 
from rainfall on the valley floor is believed to be minor in amount and to occur chiefly in wet years. The sediments along the Cuyama River channel are permeable enough to absorb almost the entire flow of the river, and only during rare floods does the river flow the whole length of its course in Cuyama Valley. The natural ground-water discharge from the valley was estimated, on the basis of data obtained prior to 1946 , to be about 8,000 acre-feet by evapotranspiration from 2,100 acres of shallow water table, plus 5,000 acre-feet by surface and subsurface outflow down the Cuyama River channel.

Ground-water development in Cuyama Valley began in the late 1930's. The irrigated acreage, increased from 400 in 1939 to 4,600 in 1941, dropped back to 3,100 in 1944 and rose to 10,000 by 1952 . Gross pumpage from wells amounted to 1,800 acre-feet in $1939,18,600$ in $1941,9,200$ in $1944,17,000$ in 1946 , and 58,000 acre-feet in 1952. Pumping has caused a marked seasonal fluctuation of water levels in wells, but throughout the wet period 1937-44 there was evidently full recovery after the cessation of pumping. During the dry period 194556 , however, there was a progressive decline of water levels in wells in the pumped area, amounting to 15 feet or more in some wells. Even greater declines have been recordled in observation wells in the recharge area; for example, in well 9/24-19Q1 near the Cuyama Ranger Station at the upper end of Cuyama Valley the water level rose about 5 feet in 1943 and 14 feet in 1944, apparently because of recharge; from 1944 through 1955, however, the record has been one of progressive decline, aggregating about 60 feet. This decline is attributed to gradual draining and natural discharge, during the drought, of water that had been stored during the preceding wet period.

\section{SANTA YNEZ RIVFR BASIN}

The Santa Ynez River has a drainage basin of about 900 square miles, half of which is a mountainous headwater area that is the source of about three fourths of the water supply of the basin. Water is used in the lower part of the basin, chiefly on the Lompoc Plain near the Pacific Ocean, but also on narrow flood plains and upland areas upstream. The water of the Santa Ynez River is also exported from the basin to communities on the south coast.

The runoff of the Santa Ynez River at Robinson Bridge in Lompoc has ranged from no flow in 1951 to 652,000 acre-feet in 1941, and has averaged 83,400 acrefeet in the period 1926-55. Inasmuch as the seepage from the river downstream from this bridge is probably not more than 3,000 acre-feet a year, these figures also indicate approximately the volume of wastage to the ocean. The Cachuma dam, constructed in order to hold back some of this surplus, was completed late in 1955. The hydrology of the Santa Ynez River Basin has been described by Upson and Thomasson (1951) and by Wilson (1959). As shown by these reports and other data, water has been diverted from the Santa Ynez River since 1920 at Gibraltar Dam for the city of Santa Barbara, and since 1930 at Juncal Dam for the Montecito County Water District, but these diversions are small in comparison to the water pumped from wells within the basin. The largest single area of use is the Lompoc Plain along the lower reach of the river; but aggregate pumpage from wells in upstream areas near Santa Rita, Buellton, Solvang, and Santa Ynez has been increasing in recent years until it has become approximately equal to the pumpage from wells in the Lompoc Plain.

Fluctuations in annual rainfall at Santa Barbara, runoff of Santa Ynez River at Lompoc, aggregate pumpage from wells, and water levels in selected wells are shown by the graphs of figure 8 . The rainfall

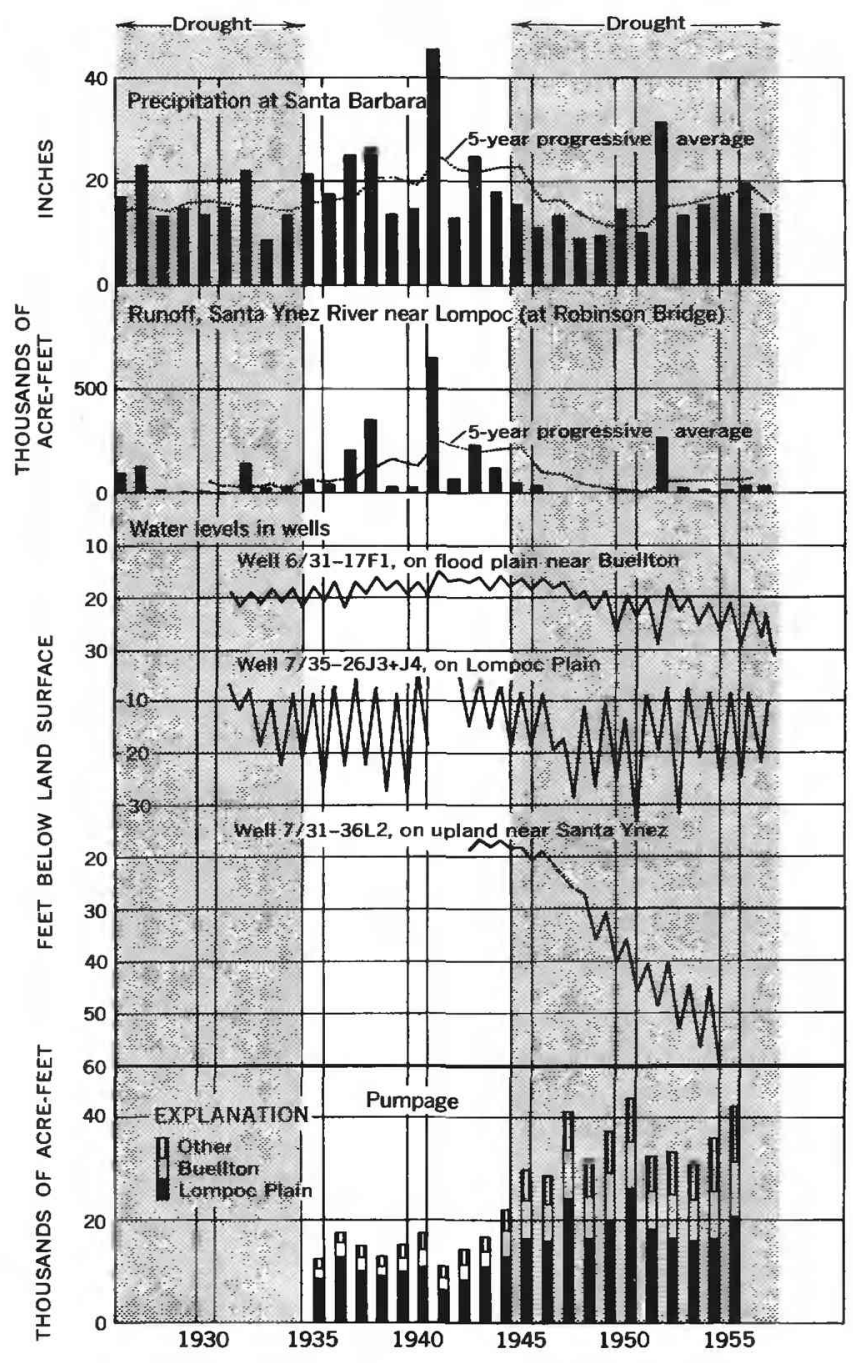

Figure 8.-Hydrologic trends in Santa Ynez River basin. 
graph indicates that the periods $1923-35$ and $1945-57$ were mostly dry, and the intervening years 1936-44 were wet. These alternating wet and dry periods are reflected in the runoff and in the water levels in wells. The irrigated acreage in the Santa Ynez basin has increased since 1935, and the pumping of water from wells has risen in consequence. But the amount of pumping has also been responsive to natural climatic fluctuations, for it was less in the wet year 1941 than it had been in any of the preceding 6 years, and greater in the dry year 1950 than in any subsequent year. The well hydrographs illustrate the wide range of fluctuations that have been observed in various parts of the Santa Ynez River basin. Well 6/31-17F1 is on the flood plain near Buellton, and within 1,500 feet of the river channel; replenishment from the river is sufficient to prevent permanent depletion of ground-water storage, although the water level in the well has been lowered each summer and in dry years has not fully recovered. In well $7 / 35-26 \mathrm{~J} 3$ on the Lompoc Plain about 4 miles west of Lompoc, there was full recovery of water levels from seasonal pumping during the wet period 1937-44, and during the wet year 1952 . By contrast, well 7/31-36L2 is on the uplands near Santa Ynez, where, because the water-bearing materials are hydraulically isolated from the river, the pumping has been chiefly from storage, and depletion has resulted since 1945; nevertheless, the hydrograph suggests that there may have been some replenishment in 1952.

\section{SOUTH COAST BASINS}

The small Goleta and Carpinteria ground-water basins, respectively west and east along the coast from Santa Barbara, have been described by Upson (1951). In both basins water occurs in unconsolidated sediments that extend more than 2,000 feet below sea level, although water wells are generally less than 400 feet deep, and little is known of the quality of water in the sediments of greater depth. Most of the wells tap aquifers where the water is confined beneath alluvial clay and silt. The ground-water reservoirs in the basins are recharged both by direct penetration of rainfall and by seepage from small ephemeral streams that drain the south slope of the Santa Ynez Mountains. In both basins the ground-water reservoirs are separated from the Pacific Ocean by relatively impermeable consolidated rocks along the coast.

Maps of the Lompoc Plain along the Santa Ynez River, and the Goleta and Carpinteria basins are shown in figures 9 and 10 . These maps indicate the amount of decline of water levels in wells during the 6-year period from 1945 to 1951 . The declines shown by these maps do not necessarily indicate corresponding changes in ground-water storage, because many of the wells tap confined aquifers, but they do suggest that there has been some depletion of storage since 1945. Also included in the figures are hydrographs for a representative well in each of the three areas, which show the changes of water level at the selected wells during the period of record. The figures are adapted from illustrations contained in Wilson's (1957) paper.

\section{QUESTION OF OVERDRAFT}

The maps of figures 9 and 10 show that the development and utilization of wells in the Goleta and Carpinteria basins and in the Lompoc Plain have been accompanied by a substantial lowering of water levels in the wells. The hydrographs for wells tapping each of these ground-water reservoirs show that the rate of lowering is correlative in part with the rate at which water is withdrawn from the reservoir, and in part with the presumed fluctuations in recharge during alternating wet and dry periods. A similar history, with local variations, is recorded by hydrographs for wells in Santa Maria Valley (fig. 7) and Oxnard Plain (fig. 6), and for wells tapping several ground-water reservoirs farther south (figs. 2, 5). In each of these basins the same general conclusions may be reached-that the ground-water storage is now less than it was under natural conditions and the total discharge from the reservoir must therefore have exceeded the total recharge to the area. These conclusions raise the question whether these reservoirs are being overdrawn, and if so, where and how much?

The authors of the present report have been conservative in the use of "overdraft" and "safe yield" and have generally used quotation marks to indicate that the terms have already been applied in published descriptions of the conditions. We are not alone in this conservatism: The California Department of Water Resources considers "overdraft" to occur only where the depletion of storage results in some adverse condition, and cites as examples (Richter, 1956) (a) sea water intrusion, (b) upward or lateral movement of unusable ground water, (c) interchange of water of differing mineral charactistics, (d) downward movement of unsuitable perched water, (e) adverse salt balance, and (f) land subsidence. In the ground-water reservoirs of the Santa Barbara region where depletion of storage is undeniable, an important question is whether the resulting conditions are indeed adverse.

Scanning the natural conditions of water supplyrainy winters and rainless summers, alternating wetter and drier periods each of several years duration, and wastage to the oceans that varies with the wetness-it is evident that mankind for existence in the region re- 


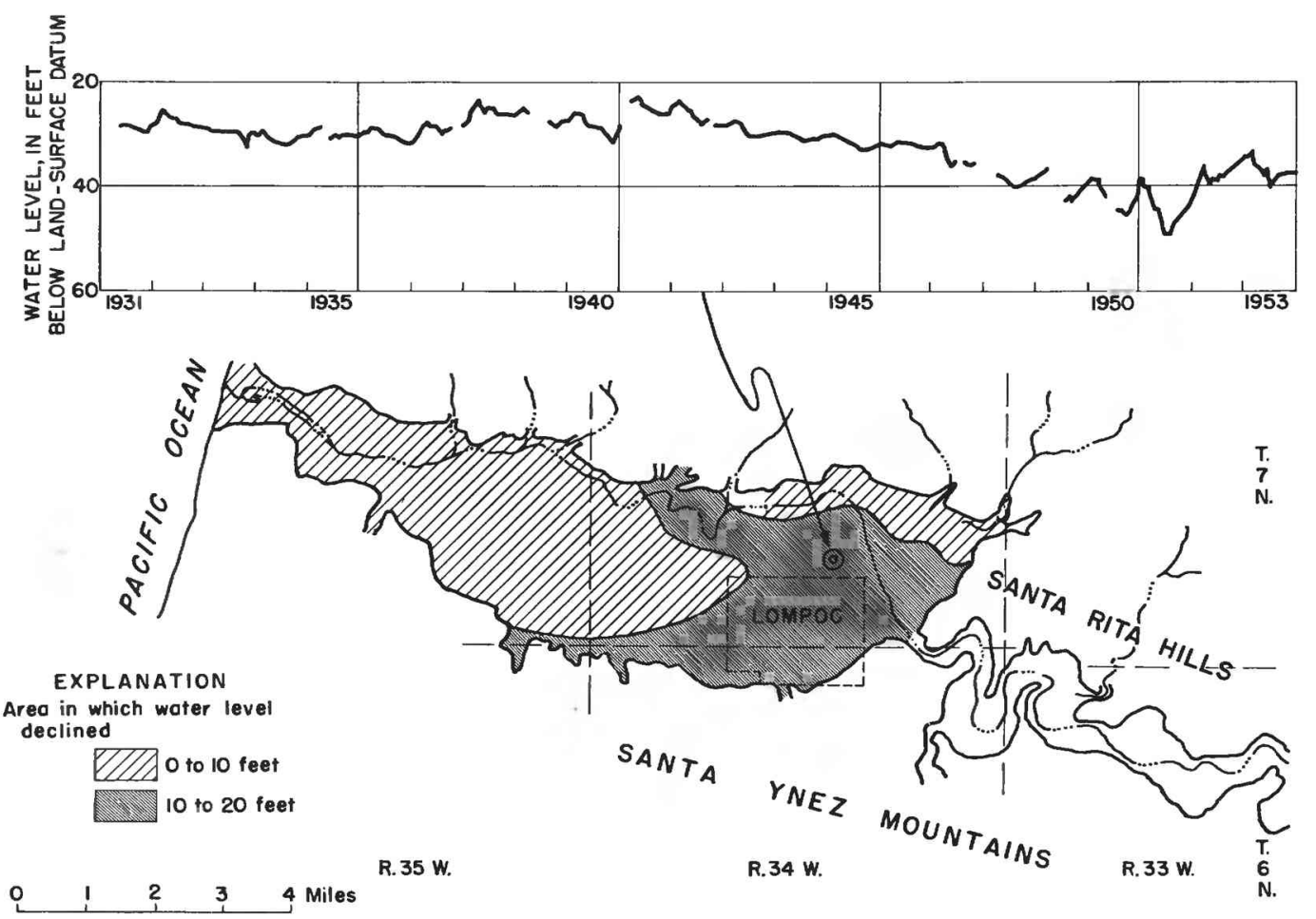

LOMPOC PLAIN

Figure 9.-Map showing net change of ground-water level, 1945-51, in Lompoc Plain along the Santa Ynez River.

quires storage facilities that can hold surplus water from winter to summer, and from wet cycle to dry cycle: Thus it would be possible to make beneficial use of water that would naturally waste to the ocean. In the area of most concentrated population, along the south coast, the small ground-water reservoirs and short ephemeral streams are clearly inadequate for the needs. Diversions from the Santa Ynez River, with storage behind Gibraltar and Juncal Dams, provided an answer for a small population, and the recently completed Cachuma Dam provides the storage for a much larger population. Until Cachuma Reservoir had filled sufficiently to permit diversions through Tecolote tunnel, the ground water in the Goleta and Carpinteria reservoirs was drawn from storage as necessary to meet requirements; this storage depletion occurred chiefly during the dry period $1945-51$. Since 1952 the withdrawal from wells has not greatly exceeded the supply, partly because of contributions as great as 5,000 acre-feet a year from the Tecolote tunnel during construction. With Cachuma Reservoir available, the south coast ground-water reservoirs can continue to provide a proportion of the requirements of the area without adverse results. The water levels have been lowered below sea level in parts of the south coast basins, but the barrier along the coast may prevent or at least hinder en- croachment of sea water. Pumping from below sea level may or may not be an adverse condition in these coastal basins, and the effects must be watched closely.

The ground-water reservoir under Lompoc Plain, along the Santa Ynez River, is not known to be separated from the Pacific Ocean by any barrier, although the alluvial sediments doubtless become progressively finer seaward. A seaward gradient had been established by natural movement of fresh water to the ocean, and reversal of this gradient at the coast would induce encroachment of sea water into the ground-water reservoir. Fortunately, the artesian pressures in the wells nearest the ocean in $\mathbf{1 9 5 6}$ were still sufficient to raise the water above sea level. As shown by figures 9 and 10 , water levels have been lowered less in wells near the coast than in wells farther inland, as for example near Lompoc. Unless and until sea water moves into the ground-water reservoir under the Lompoc Plain, the lowering of water levels cannot be labelled undesirable, because one effect of this lowering is to reduce the rate of fresh-water underflow to the ocean.

The water users within the Santa Ynez basin, including those on the Lompoc Plain, fear that the diversions from Cachuma Reservoir through Tecolote tunnel may reduce the quantities available for their use. The records of wastage to the ocean in past years, however, in- 

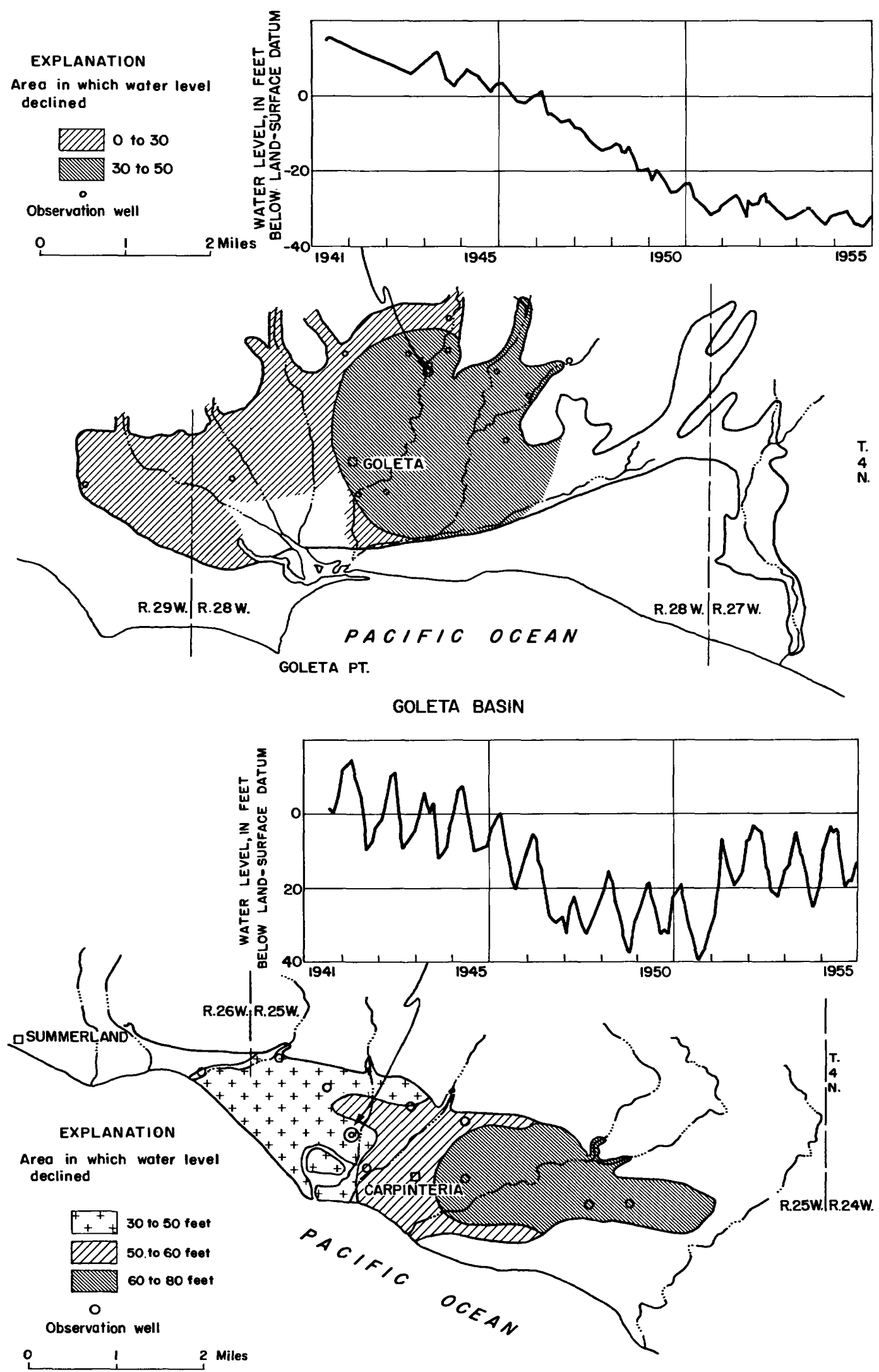

CARPINTERIA BASIN

Figdre 10.- Maps showing net change of ground-water level, 1945-51, in the south coast basins, Santa Barbara region. 
dicate that the Cachuma Reservoir can be operated to provide adequate supplies for more than the present users dependent upon the Santa Ynez basin. Such operation would need to reduce to a minimum the wastage to the ocean and would use the water instead to recharge the ground-water reservoirs downstream along the Santa Ynez as well as those along the south coast. Removal of ground water from storage would be an essential part of the operation in some periods.

In the Santa Maria River basin the only existing facilities for salvaging the natural wastage to the ocean and storing it for beneficial use are the ground-water reservoirs of Santa Maria Valley and Cuyama Valley. ${ }^{1}$ Reduction of ground-water storage in dry periods, which will create space for recharge in wet periods, is an essential part of this salvage operation. As pointed out on pages G13-G15, the development of the ground-water reservoir has been accompanied by a loss of storage that may be permanent, and this has been called "overdraft" by many observers. But if the ultimate result is a modified equilibrium in which natural discharge to the ocean is replaced by discharge from pumped wells, the depletion of storage is not "bad." Records to date indicate that the wastage to the ocean has decreased in recent years, but because of progressively increasing draft, the modified flow system has not yet reached a new equilibrium.

By pumping from wells, the residents of Santa Maria Valley have been able to salvage most of the water that once discharged naturally into the ocean, and the ground-water reservoir has served to regulate and stabilize the highly variable quantities that are delivered from the mountainous headwaters. Whether the resource can meet the present requirements perennially, however, depends upon future climatic fluctuations and also upon the effect on Cuyama River flow of the increasing utilization of water in Cuyama Valley. It is recognized that the ground-water reservoir in Santa Maria Valley, like that of the Lompoc Plain, is not insulated from the ocean, and vigilance is therefore necessary to prevent conditions favorable to sea-water intrusion.

\section{UPPER SALINAS RIVER BASIN}

By J. S. Gatewood and Alfonso Wilson

Virtually the entire economy of the upper Salinas River basin in San Luis Obispo County is predicated upon an adequate supply of ground water of good quality for irrigation. Under usual crop practices,

\footnotetext{
1 The Twitchell dam, authorized by Congress in 1954, will create a reservoir on Cuyama River above its confluence with the Sisquoc River having a capacity of 239,000 acre-feet.
}

with two or more crops planted per year in some localities, the average annual consumptive use of water has been estimated to be about 2.1 acre-feet per acre, of which about 0.9 acre-foot per acre is supplied directly by precipitation. Thus about 1.2 acre-feet per acre must be supplied by irrigation, mostly by pumping ground water.

Except as a source of recharge to ground water by percolation of streamflow in the channels of Salinas River and its tributaries, surface water plays a small part in the economy of the Salinas River basin. The only important direct use of surface water for irrigation is in the Greenfield area of lower Salinas Valley where supplemental early-season water is obtained by gravity from Arroyo Seco through Clark Canal. In a normal year about 4,000 acre-feet of water is supplied from this canal.

Use of water in the basin, other than for irrigation, amounted to about 16,000 acre-feet a year during the period 1945-55, of which about 6,000 acre-feet was used by business and industrial establishments and about 10,000 acre-feet for domestic supply in rural areas, recreational areas, and military establishments. Most of this 16,000 acre-feet was pumped from wells, but the Salinas Reservoir, in the headwaters of Salinas River near Santa Margarita, provided about 2,600 acre-feet of impounded water yearly for municipal use at San Luis Obispo and the adjoining military Camp San Luis Obispo.

The 1945-57 drought had no significant effect on agricultural or municipal water supply in the Salinas River basin despite increased population and industry. Any small diminution in surface runoff was more than made up from ground water without serious overdraft on the aquifers. The irrigated acreage increased from 112,000 in 1944 to 140,000 in 1949 and 149,000 in 1954. During this period, there were no crop failures and no special water conservation measures were necessary because of drought. Between 1945 and 1955 about 225 stockwatering ponds having an average capacity of 4.3 acrefeet were constructed, chiefly for the purpose of lengthening the grazing season by obtaining a better distribution of use of the range and not particularly because of drought.

Storage in Salinas Reservoir fluctuated considerably from year to year but was higher at the end of 1955 than it had been at the end of most years since its construction in 1941. Some small decline was noted in the discharge of springs in Salinas River basin between 1945 and 1955, but the principal fluctuations were in response to variations in annual rainfall; the fluctuations lagged about a year behind the rainfall variations. 


\section{SOUTHERN SAN JOAQUIN VALLEY}

\section{By George H. Davis}

The southern San Joaquin Valley is only partly within the area of long-continued drought in the Southwest (Thomas, 1962). Precipitation at Bakersfield has been significantly less than the long-term average in 9 of the 11 years 1946 to 1956 ; this drought and records from other valley stations are chiefly responsible for the position of the line defining the northern limit of the drought across the San Joaquin Valley. The principal use of water in the valley is for crop watering; municipal, industrial, and domestic uses are small in comparison to water used for irrigation. The annual rainfall in the valley is low ; it averages only 6 inches at Bakersfield, and much moisture is dissipated as evaporation following storms. Furthermore, most of the rain falls in the winter months when few crops are growing. Accordingly, variations in precipitation on the valley floor are of only minor significance in the overall water-supply picture. Streamflow, the critical quantity in the water supply, depends almost wholly on the amount and distribution of precipitation in the mountains that border the valley.

Although the annual runoff of the Kern River, the chief water supply of the southern part of the valley, has been significantly below the long-term average in 8 of the 10 years $1947-56$, runoff of 1952 virtually wiped out the accumulated deficiency of runoff during the previous years of drought, and in subsequent years runoff has been near the average. Streamflow and precipitation in the southern San Joaquin Valley are marginal with respect to the Southwest drought.

The San Joaquin Valley is a broad structural trough surrounded by mountains: the Sierra Nevada on the east, the Tehachapi Mountains and San Emigdio Range on the southeast and south, respectively, and the Coast Ranges on the west. The principal source of water for the valley is the Sierra Nevada which rises in a distance of 45 to 60 miles to altitudes exceeding 12,000 feet. As storms sweeping inland from the Pacific Coast ascend the western slope of the Sierra Nevada, precipitation increases and reaches a maximum in the higher parts of the range. In the winter months, snowfall is heavy above the 4,000 foot level. This snowpack acts as a natural storage reservoir retaining most of the winter precipitation until the late spring and early summer. The Coast Ranges yield little water to the San Joaquin Valley, because most of the drainage is westward to the Pacific Ocean; the eastern slopes, which are tributary to the San Joaquin Valley, lie in a rainfall shadow and are semiarid. Likewise, the San Emigdio Range and Tehachapi Mountains yield little water to the valley because of low precipitation. It has been estimated by the California Division of Water Resources (1951, p. 407) that mean seasonal runoff to the San Joaquin Valley from all streams south of the Kern River and from streams in the southern 100 miles of the west side of the valley totals only about 140,000 acre-feet.

The southern fringe of the San Joaquin Valley, south of the Kern River, is an area of low streamflow and heavy ground-water withdrawals for irrigation. Withdrawals greatly exceed the total replenishment and water levels have declined steadily as ground-water storage was depleted. Under this mining regime, the effect of the drought is relatively insignificant in the overall water deficiency. The western slope of the valley is also an area of generally deficient water supply, where rainfall is meager and the stream courses carry little water and where the only significant agricultural activity is winter grazing. Deficient rainfall in the drought period 1946-56 resulted in inferior grazing conditions throughout the west side of the valley and the adjoining Coast Range foothills.

Because the drought in the southern San Joaquin Valley has principally affected the water supply of the Kern River, a detailed discussion is confined to the water-service area of the Kern.

\section{KERN RIVER SERVICE AREA}

The Kern River drains 2,420 square miles of the southern Sierra Nevada including some of the highest terrain in the United States near Mt. Whitney, altitude 14,495 feet. It debouches upon the floor of the San Joaquin Valley near Bakersfield, at about 400 feet altitude. From Bakersfield the Kern flows westward across the San Joaquin Valley about 18 miles to Elk Hills where it splits, one fork discharging northward to Tulare Lake, the other southward to Buena Vista Lake. Both lakes are basins of interior drainage under the present flow-regime; but in the historic past the rims of both basins have been overtopped during floods which established through-flow along the entire length of the San Joaquin Valley and thus prevented extensive evaporite accumulation.

The Kern River is the only important water supply to the southern San Joaquin Valley, because local precipitation is generally too low and occurs at the wrong time of year to be of benefit to most crops. Likewise, precipitation is generally too low to be a material factor in ground-water recharge because little or no deep penetration of rainfall occurs in most years, and precipitation on the valley floor does little more than lay the dust. The flow of the Kern River, on the other hand, is used to the fullest extent. Because the bulk of the runoff occurs during the snowmelt of late spring and early 
summer, much of the flow is diverted directly for irrigation. Surplus flows are stored for later use at Isabella Reservoir, about 40 miles upstream from Bakersfield, and at Buena Vista Lake in the trough of the valley. The Kern River is also the ultimate source of recharge to the ground water in the area: Replenishment occurs chiefly by seepage from the channel of the river and from canals, by deep percolation of water applied for irrigation in excess of plant requirements, and by spreading of surplus water for ground-water recharge.

\section{STREAMFLOW}

The runoff of the Kern River is directly related to the amount of precipitation in its mountain drainage area, but because most of the total precipitation above the 4,000 feet altitude falls as snow, the time distribution of the precipitation is not closely related to the time of the consequent runoff. No long-term precipitation records are available from stations above 2,500 feet altitude, hence no direct comparison can be made between precipitation and runoff; however, there are records beginning in 1930 of the water content of the snowpack each April 1 at several snow courses in the basin. A bar graph of the record of a typical snow course-at Round Meadow, altitude 9,000 feet-is presented on figure 11 for comparison with the graphs of annual precipitation at Bakersfield and runoff of the Kern River. A direct correlation is apparent, although early snowmelt may disturb the relationship, as in 1951 when snow on the ground on April 1 contained only 3 inches of water despite the fact that runoff in 1951 was near the long-term mean. The record of annual runoff of the Kern River near Bakersfield is a better index of the water yield from precipitation than records of such precipitation would be even if they existed because : (a) it integrates the runoff of the whole basin at a single station, (b) diversions and storage above Bakersfield were minor until the completion of Isabella Dam in 1954, and (c) owing to the bare terrane and impermeable nature of the rocks of the basin, little water is retained beyond the snowmelt period to supply groundwater base flow and, accordingly, natural carryover storage in the basin is relatively small.

The annual flow of the Kern River is notable for its variation compared to the major streams draining the central and northern part of the Sierra Nevada. During the 36-year base period illustrated on figure 11, the annual runoff ranged from a minimum of 195,000 acrefeet in 1931, or 30 percent of the mean, to $1,479,000$ acre-feet in 1952, or 227 percent of the mean. The accompanying graph of accumulated departure of annual runoff illustrates long-term variations in streamflow. Periods of above-average flow are represented by a rising trend and periods of below-average flow by a declining trend. The curve clearly delineates a 13 -year dry period, 1923-35, followed by an 11-year wet period, 1936-46. The succeeding 10 years, 1947-56, correspond to the Southwest drought. However, the runoff of 1952 erased the cumulative deficit of the previous 5 years and built up a surplus in the water account that had not been seriously depleted as of 1956 .

Little water escapes from the Kern service areas as surface outflow. Even in the flood year 1952 only about 20,000 acre-feet of surface outflow is estimated to have escaped northward to the Tulare Lake basin. Water not utilized in the year it is generated is carried over for use in later years as surface storage at Buena Vista Lake and Isabella Reservoir, or is placed in groundwater storage by means of controlled spreading in recharge basins supplemented by flood irrigation of marginal pasture lands that receive little water in other years. Carryover storage in surface reservoirs for the period 1937-56 is illustrated on the graph of annual flow of the Kern River.

\section{GROUND WATER}

The "Kern River service area" as the term is used herein contains approximately 580,000 acres or about 900 square miles, chiefly on the alluvial fan of the Kern River. It includes all areas served by canals diverting from the Kern River as well as intervening areas that are dependent entirely upon wells. The river is the ultimate source of replenishment to the ground-water body; this replenishment occurs chiefly by seepage from the channel of the river and from canals, by deep percolation of surface water applied for irrigation in excess of plant requirement, and by artificial recharge involving planned spreading of water. The Geological Survey has estimated that replenishment to ground water from all sources (including return of pumped ground water) was approximately one-half million acre-feet in the flood year 1938 and one million acre-feet in the wetter year 1952. During periods of lower water supply, the replenishment to ground water is proportionally smaller owing to decreased recharge opportunities.

An earlier study by the Geological Survey (Davis and others, 1956) indicated that, as of 1952 , ground water was moving radially away from a broad water-table ridge beneath the Kern River toward areas of groundwater discharge, chiefly areas of heavy pumping, located around the perimeter of the alluvial fan of the Kern River. It was concluded that ground-water inflow to the Kern River area was negligible. In the central part of the Kern River fan, ground water is pumped from essentially unconfined deposits but, around the perimeter of the fan, confinement has been recognized in several places. 

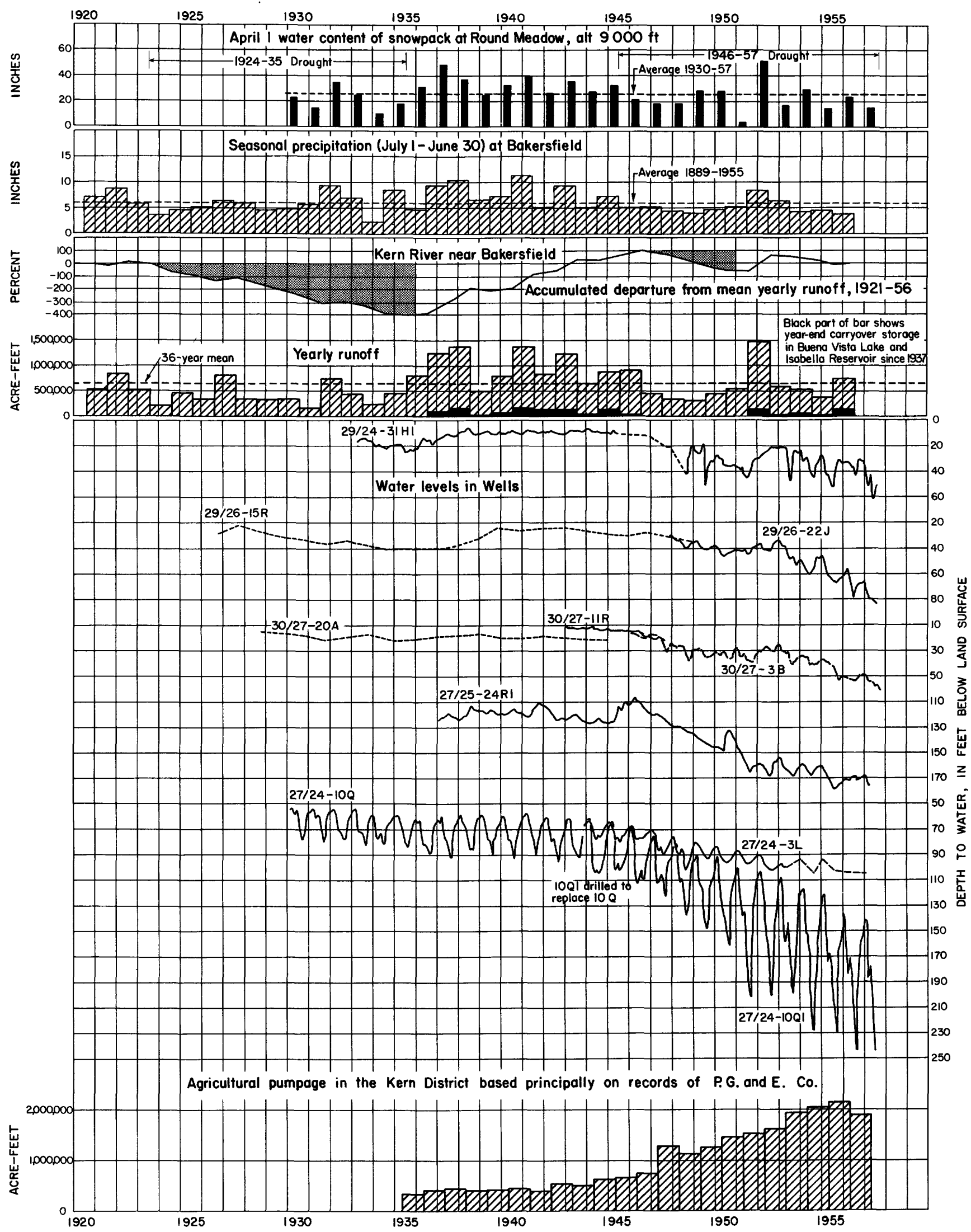

FIGURE 11.-Hydrologic data for southern San Joaquin Valley. 
Hydrographs of several wells in the Kern River service area are presented on fig. 11 to illustrate groundwater fluctuation during the drought of 1947-57. The hydrographs are somewhat similar to the accumulateddeparture curves for the annual runoff of the Kern River. Periods of increasing ground-water storage are represented by rising water levels and decreasing storage by declining water levels. There is a general correlation between the accumulated-departure curve and the hydrographs for the period prior to the recent drought. However, during the recent drought the water levels have departed from the trend indicated by the river flow and show heavy depletion of groundwater storage. The reason for this depletion lies not only in the deficient water supply from the Kern River, but, more significantly, in the increased utilization of ground water during the period of high crop prices following World War II. The magnitude of this increased pumpage is shown by the graph of agricultural pumpage in the Kern District of the Pacific Gas and Electric Co., presented at the bottom of figure 11. The Kern District includes the Kern River service area, as used here, and also the areas of ground-water service around its perimeter. The graph indicates that annual pumpage was fairly constant at 410,000 acre-feet during the prevailingly wet years from 1935 to 1941 , a period of above-average water supply. Because of increased demand and higher prices during World War II, the pumpage increased gradually from about 546,000 acre-feet in 1942 to about 762,000 acre-feet in 1946 although in these years also precipitation and streamflow were generally above average. After the war, continued high prices and readily available pumps, well casing, and other capital goods caused a great expansion of irrigation agriculture. Much new land was put under cultivation, and much land formerly farmed sporadically was used more intensively. Because firm supplies of surface water were already fully utilized, this expansion was accomplished by greater use of ground water. Accordingly, pumpage increased from 762,000 acre-feet in 1946 to almost $1,300,000$ acre-feet in 1947 , then somewhat more gradually to a maximum of 2,140,000 acre-feet in 1955. Owing to crop-acreage limitations, pumpage declined to $1,890,000$ acre-feet in 1956. The number of pumps in operation in the Kern District increased from 2,500 in 1945 to 5,740 in 1956 . Acreage farmed has not shown the same consistent growth as the pumpage owing to government acreage limitations in several years; however, the irrigated acreage in the Kern District of the Pacific Gas and Electric Co. increased from slightly less than 400,000 acres in 1945 to a maximum of 665,000 acres in 1954 . The lack of correspondence between irrigated acreage and ground-water pumpage can be explained by the fact that in years when acreage cutbacks are made, most farmers apply more irrigation water to the remaining acreage in an effort to get maximum production per acre.

The hydrograph of wells $29 / 26-15 \mathrm{R}$ and $29 / 26-22 \mathrm{~J}$, about 10 miles west of Bakersfield, illustrates fluctuations of ground-water levels in an area north of the Kern River irrigated chiefly by ground water in recent years. Annual measurements in well $15 \mathrm{R}$ from 1926 through 1935 show a close correlation with the accumulated-departure curve for Kern River during a period of less than average runoff. During the succeeding period of above-average runoff from 1936 through 1946, the correlation is poorer. Water levels in the well rose sharply from 1936 to 1939 , correlative with increased streamflow, but apparently the 1939 water level represented full capacity of the ground-water reservoir, because the succeeding years of above-average streamflow through 1946 failed to cause any further appreciable rise in water level. The ensuing period of belowaverage runoff, 1947-51, was marked by a gradual decline of about 10 feet in well 22J. The heavy runoff of 1952 is reflected in a rise of water level of about 4 feet during the year. The succeeding years through 1957 are marked by rapidly declining water levels averaging about 10 feet per year. Decreased recharge from surface water accounts for some part of the decline, but increasing ground-water draft probably is responsible for the acceleration in decline during recent years.

The hydrograph of well $29 / 24-31 \mathrm{H} 1$, about 25 miles west of Bakersfield, illustrates fluctuation of water levels in an area that receives its irrigation supply principally from canals diverting water from the Kern River. The water deliveries of this district are stabilized by storage in Buena Vista Lake, which makes possible a more stable supply throughout the irrigation season and permits some carryover storage of surplus water. During the period of deficient runoff prior to 1935 , the water level fluctuated within an annual range of about 7 feet; during the succeeding period of aboveaverage runoff in the Kern River from 1936-46, the annual fluctuations were generally smaller, about 4 feet in most years. Evidently, the ground-water reservoir reached full capacity by 1938 and only the small seasonal depletion was being replenished during the latter part of the wet cycle of $1936-46$.

The 1946-56 drought has been marked by a substantial decline in water levels in well $29 / 24-31 \mathrm{H} 1$. The pronounced seasonal fluctuations during the drought have resulted from heavy ground-water pumping to supplement the deficient surface supply. If seasonal declines are ignored, however, and a line is drawn con- 
necting the annual high-water level, the resulting curve resembles the accumulated-departure curve for the runoff of the Kern River and suggests that there is little or no overdraft on the ground-water reservoir.

The combination hydrograph of wells $30 / 27-20 \mathrm{~A}$, $30 / 27-11 \mathrm{R}$, and $30 / 27-3 \mathrm{~B}$, respectively about 7,4 , and 4 miles southwest of Bakersfield, illustrates fluctuations of the water table in an area immediately south of the Kern River which in the past was supplied chiefly from the Kern River but in recent years has seen heavy ground-water withdrawals. The hydrograph shows that annual fluctuations of the water table were minor from 1928 through 1945 despite marked fluctuations in the surface-water supply and suggests that the groundwater reservoir was maintained at or near capacity during that period. The record for 1946 and subsequent years illustrates the effect of increased use of ground water in an area previously irrigated almost exclusively by surface water. Development of ground water as a supplemental irrigation supply has continued through rhe recent drought period. The seasonal range in water-level fluctuation increased from about 5 feet in 1942-46 to as much as 19 feet in the following years. Furthermore, the general trend of the water levels began to follow the accumulated-departure curve of the Kern River. The curves correlate closely in the period 1946-52, but since 1952 the water-level graph has declined somewhat more sharply than the accumulateddeparture curve.

Well 27/25-24R1, about 18 miles northwest of Bakersfield, is representative of wells in an area supplied in part by water from the Kern River but in large part by ground water; the area has had a long history of changes in ground-water storage. A well drilled in this vicinity during the construction of the first canals to serve the area showed water standing at 105 feet below land surface in 1876. By 1920, the water table had risen 49 feet under the influence of heavy application of surface water for irrigation. Pumping of ground water during the 1920's caused depletion of storage, and by 1936 the water level was again more than 100 feet below the land surface. The drought beginning in 1946 has been marked by progressive depletion of ground-water storage owing in part to deficient surface supply but largely to development of new ground-water supplies.

The combination hydrograph of wells $27 / 24-10 \mathrm{Q}$, 27/24-10Q1, and 27/24-3L, about 26 miles northwest of Bakersfield, illustrates fluctuations in deep and shallow wells respectively in a ground-water service area near the perimeter of the Kern River service area. The sharp seasonal fluctuations in wells $27 / 24-10 Q$ and
27/24-10Q1, 264 and 430 feet deep, respectively, indicate that both wells tap confined aquifers. The small seasonal fluctuation and gentle decline in water level in well 27/24-3L, 138 feet deep, is interpreted as indicating that this well taps an unconfined shallow-water body. The deeper, confined water has fluctuated within an annual range that increased from about 30 feet before 1944 to 105 feet in 1956. Furthermore, during the years since 1944 both the summer-low level and winterhigh level have declined concurrently with the increase in seasonal fluctuation. The marked increase in annual fluctuation evidently is the result of increasing groundwater pumpage in the area, but the long-term decline in the winter-recovery level beginning as early as 1942 and continuing through 1957 indicates that withdrawal of ground water locally has exceeded replenishment during the period. Comparison of this graph with the accumulated-departure curve of annual runoff of the Kern River, which is the ultimate source of replenishment to the area, shows that the winter-recovery level followed a trend similar to the departure curve until about 1941. Since 1942, however, fluctuations in runoff have had little noticeable effect on the curve of the piezometric surface of the confined water.

The water table at well $27 / 24-3 \mathrm{~L}$, has fluctuated within an annual range of only 10 to 12 feet since 1944 . The gentle decline of about 32 feet from 1944 to 1955 corresponds to the period of the Southwest drought, but the general increase in ground-water draft during the same period may well be the chief cause for the decline.

\section{REFERENCES CITED}

Oalifornia Division of Water Resources, 1930, Report to Legislature of 1931 on State Water Plan: California Div. Water Resources Bull. 25, 204 p.

California Water Resources Board, 1951, Water resources of California : Bull. 1, 648 p.

1953, Elsinore basin investigation: Bull. 9, $59 \mathrm{p}$.

1953 [revised 1956], Ventura County investigation: Bull. 12, vol. 1, 489 p. ; v. 2, 9 app. and $15 \mathrm{pl}$.

1955, Water utilization and requirements of California: Bull. 2, v. 1, 226 p. ; v. 2, p. 227-358 and 15 pl.

Conkling, Harold, 1946, Utilization of ground-water storage in stream-system development: Am. Soc. Civil Engineers Trans., v. 111, p. 279-280.

Davis, G. H., Green, J. S., Olmsted, F. H., and Brown, D. W., 1959, Ground-water conditions and storage capacity in the San Joaquin Valley, California: U.S. Geol. Survey Water Supply Paper 1469, 277 p., 29 pl.

Eckis, Rollin, 1934, Geology and ground-water storage capacity of valley fill (South Coastal Basin investigation): California Div. Water Resources Bull. 4, 273 p.

Gatewood, J. S., Wilson, Alfonso, Themas, H. E., and Kister, Lester, 1963, General effects of dro'ight on water resources of the Southwest: U.S. Geol. Survy Prof. Paper 372-B. (In press.) 
Gleason, G. B., 1947, Overdraft on ground-water basins (South Coastal Basin investigation): California Div. Water Resources Bull. 53, $252 \mathrm{p}$.

Laverty, F. B., 1957, Water-spreading activities of the Los Angeles Flood Control District: Committee on Research in Water Resources, Proc. Conf. Water Spreading for Ground-Water Recharge, p. 14-20.

Richter, R. C., 1956, Overdraft conditions in California groundwater reservoirs and effects: California Div. Water Resources, 12 p. [Mimeographed report.]

Schulman, Edmund, 1947, Tree-ring hydrology in southern California : Arizona Univ. Lab. Tree-Ring Research, Bull. 4.

Stafford, H. M., and Troxell, H. C., 1953, Coastal basins near Los Angeles, Calif. in Subsurface facilities of water management and patterns of supply-type area studies, $\nabla .4$ of Physical and Economic Foundations of National Resources: U.S. Cong., House Comm. Interior and Insular Affairs, p. 21-50.

Thomas, H. E., 1962, Meteorological phenomenon of drought: U.S. Geol. Survey Prof. Paper 372-A, 43 p.

Thomas, H. E., and others, 1963, Effects of drought in basins of interior drainage: U.S. Geol. Survey Prof. Paper 372-E $50 \mathrm{p}$.
Troxell, H. C., 1957, Water resources of southern California with special reference to the drought of 1944-51, U.S. Geol. Survey Water-Supply Paper 1366, $136 \mathrm{p}$.

Upson, J. E., 1951, Geology and ground-water resources of the south-coast basins of Santa Barbara County, California: U.S. Geol. Survey Water-Supply Paper 1108, 140 p.

Upson, J. E., and Thomasson, H. G., Jr., 1951, Geology and water resources of the Santa Ynez River basin, Santa Barbara County, California: U.S. Geol. Survey Water-Supply Paper 1107, $189 \mathrm{p}$.

Upson, J. E., and Worts, G. F., Jr., 1951, Ground water in the Cuyama Valley, California: U.S. Geol. Survey WaterSupply Paper 1110-B, p. 21-80.

Wilson, H. D., Jr., 1957, Utilization of ground-water basins in Santa Barbara County, California, during 1945-52: Am. Geophys. Union Pacific Section mtg., Sacramento, Calif. 1959, Ground-water appraisal of Santa Ynez River basin, California, 1945-52: U.S. Geol. Survey Water-Supply Paper 1467, $116 \mathrm{p}$.

Worts, G. F., Jr., 1951, Geology and ground-water resources of the Santa Maria Valley area, California : U.S. Geol. Survey Water-Supply Paper 1000, 165 p. 